\title{
Culture and Corporate Governance: The Influence of Language and Religion in Switzerland
}

\author{
Christophe Volonté
}

Received: 28 May 2013/Revised: 30 June 2014/Accepted: 15 July 2014/

Published online: 6 September 2014

(C) Springer-Verlag Berlin Heidelberg 2014

\begin{abstract}
We investigate the effect of culture on corporate governance using the extraordinary opportunity that the corporate landscape of Switzerland provides. Within a single institutional framework (e.g., Swiss federal corporate law), we use language (German and French) and religion (Roman Catholicism and Protestantism) as proxies for culture. These groups share a distinct set of values particularly in their tolerance for hierarchical structures. We observe that firms in Swiss-French areas and firms in Roman Catholic cantons are more likely to have one-tier boards, whereas two-tier boards are more prevalent in Swiss-German areas and Protestant cantons. Furthermore, board composition is significantly driven by language. In contrast, ownership and equity structure are not significantly related to culture.
\end{abstract}

Keywords Corporate governance - Board of directors - Ownership structure · Culture $\cdot$ Language $\cdot$ Religion

\section{Introduction}

Economists often aim to explain cross-country heterogeneity in terms of economic features such as financial development, business practices or corporate governance (see Djankov et al. 2003; Aguilera and Jackson 2010). Typically, corporate governance can be seen as a set of devices aimed to protect (minority) shareholders against managerial misbehaviour or misbehaving (large) shareholders (see e.g., Shleifer and Vishny 1997). Corporate governance is a crucial success factor in a firm's strategy. However, striking international differences have been found in important elements of corporate governance such as the structures of the board of

C. Volonté (ه)

Faculty of Business and Economics, University of Basel, Basel, Switzerland

e-mail: christophe.volonte@unibas.ch 
directors (Wymeersch 1998) and corporate ownership (La Porta et al. 1999a; Faccio and Lang 2002).

Due to the close relationship between corporate governance and the legal system, the law and finance theory has provided the reference for explaining the various corporate governance regimes around the world (see e.g., La Porta et al. 1998). The theory of legal origins assumes that common law countries and their respective systems of corporate governance (i.e., minority investor protection, dispersed ownership, and takeover activity) are related to better economic outcomes relative to civil law countries (see e.g., La Porta et al. 2008). Higher investor protection results in a more efficient allocation of capital. In consequence, it is believed that introducing elements of Anglo-American corporate governance practices would potentially improve economic development. However, such corporate governance reforms have not per se led to greater stock market development (Armour et al. 2009). We can still observe a variety of corporate control structures around the globe. Doidge et al. (2007) find that country characteristics explain the variation of a firm's governance better than firm characteristics can. The convergence process is hampered by factors at the firm level, but also at the institutional and the national level (Aguilera and Jackson 2003; Denis and McConnell 2003; Buck and Shahrim 2005; Yoshikawa et al. 2007).

Some researchers thus claim that culture may play an important role in corporate governance practices around the world (Bebchuk and Roe 1999; Buck and Shahrim 2005; Clarke and dela Rama 2006; Aguilera and Jackson 2010). International organizations such as the World Bank, the IMF, the OECD or large pension funds such as CalPERS share this view (see Licht 2001). For instance, the business practices of American, Japanese or German managers differ, and this is likely to be associated with their underlying culture.

However, culture is a complex concept and is often regarded as a black box. In his seminal work, Hofstede (1980) defines culture as a shared set of values which separates one group of people from another. Culture is seen as being the expression of the aggregate of common individual personalities forming a group. Beliefs, values and norms constitute a "collective programming of the mind" which is deeprooted in society and therefore changes only very slowly from one generation to the next (Hofstede 1980, p. 25). Licht (2001) denotes culture as the "mother of all path dependencies", suggesting that culture is fundamental to an explanation of the global differences in corporate governance. Proponents of the new institutional theory argue that both informal institutions (e.g., culture) and formal institutions (e.g., laws) constitute the "rules of the game" according to which individuals and organizations interact. In consequence, (both) institutions affect economic outcomes (e.g., management practices, economic growth) directly and indirectly (North 1990, p. 3; Williamson 2000). Lowe (1998) contends that culture is important in the transmission process from old to new institutions combining the two perspectives. Hence, it is widely acknowledged that culture directly (Hofstede 1980) or indirectly via (formal) institutions (Williamson 2000) is important in explaining economic outcomes. However, there are various relationships between culture, institutions, corporate governance, firm performance and economic growth. Another important problem in evaluating and operationalizing culture lies in its measurement (see e.g., 
Shenkar 2001). Hofstede's basic framework measures cross-cultural differences along four dimensions of national culture (power distance, uncertainty avoidance, individualism, and masculinity) using survey data (see also Schwartz 1999). While some studies rely on such classifications of culture (e.g., Licht et al. 2005, 2007; Li and Harrison 2008; Siegel et al. 2011) or measures of cultural distance derived from Hofstede's cultural indices (e.g., Kogut and Singh 1988), other studies rely on more easily observable characteristics such as a country's predominant language or religion (e.g., Grinblatt and Keloharju 2001; Stulz and Williamson 2003; Guiso et al. 2003, 2006). Groups which speak the same language or believe in the same religion often share the same values. These values can also be identified in Hofstede's typology of cultural dimensions. However, both cultural dimensions and cultural proxies often overlap with countries and thereby their institutions. For instance, Protestantism, English and common law are commonly linked characteristics which are associated with similar corporate governance regimes.

This study investigates the effect of culture on corporate governance using the cultural pluralism within one country and one single institutional system: Switzerland. Culture is proxied by language (French and German) and religion (Roman Catholic and Protestant) which are the most important factors in Switzerland's cultural pluralism (see Mayer 1951). ${ }^{1,2}$ The literature shows that there are significant cultural differences between German-speaking people and French-speaking people as well as between Protestants and Catholics. Most importantly, French, Swiss-French, and Roman Catholics tend to tolerate hierarchical structures and strong leadership. In contrast, German, Swiss-German, and Protestants tend to be skeptical towards a concentration of power (see e.g., Hofstede 1980; Stulz and Williamson 2003). ${ }^{3}$

The distribution of power within the corporation determines the relationships between managers, controlling shareholders and (minority) shareholders and corporate governance aims to mitigate potential conflicts between these parties. We focus in our study on two relevant features of corporate governance: board of directors and ownership structure. In particular, we evaluate the impact of culture on board structures, board composition, and ownership structure. Firstly, in Switzerland, corporations can choose between two forms of board structure: one-tier and two-tier boards. The more hierarchical one-tier board consists of executives (insiders and, most frequently, the chief executive officer, CEO) and non-executive directors (outsiders) who, together, within one centralized corporate body conduct daily business and monitor the management. A two-tier board, on the other hand, consists of a management board and a supervisory board. The day-to-day

\footnotetext{
1 We restrict our analysis to Swiss-French and Swiss-German areas, because there are only four listed firms in the Italian-speaking area of Switzerland and none in the Rhaeto-Romanic area.

2 In a similar setting, Belgium's two important language regions, Flanders and Wallonia are culturally influenced by The Netherlands and France. However, unlike Switzerland, most firms are located in the bilingual Brussels area, and corporate governance does not seem to differ significantly between the two regions. In addition, Belgium has only one predominant religion which is Roman Catholic. We are grateful to Stijn De Dier (KU Leuven) for pointing us out the situation in Belgium.

3 To our knowledge, no empirical studies have used Hofstede's cultural dimension scores on the different Swiss regions other than the two language regions.
} 
management of the corporation is delegated to a management board which is completely separate from the supervisory board. Splitting the corporation's highest level of authority into an executive and control function increases the (supervisory) board's independence, promotes the sharing of tasks and responsibilities, and reduces the concentration of power. Secondly, culture also appears to affect board composition, as board members' values and beliefs determine not only who is selected for board membership but also which decisions are made and consequently how the firm is directed. Directors may be chosen because they share the same values as the other board members, and these values are likely to correspond to those of the regional culture of the firm's headquarters. These shared values may result in a uniform and distinct management style. Thirdly, the separation of ownership from control shapes the principal-agent relationships within corporations. Strong shareholders have a significant influence on the board and the corporation as a whole by using their voting rights. In more hierarchically-oriented cultures, ownership may therefore be more concentrated, especially if controlling shareholders benefit from a multiple class equity structure.

In our study, we relate distinct features of culture directly to corporate governance structures, holding institutional factors constant. We contribute to the discussion of the effect of culture on corporate governance practices for three main reasons. First of all, culture is generally difficult to operationalize. We use two languages (German and French) and two religions (Roman Catholicism and Protestantism) as measures for culture. Each of these two proxies is presumed to be linked to different tolerances for hierarchical structures and therefore have a potential impact on corporate governance. Such an approach was also recommended by Siegel et al. (2011) as a promising fruitful way to study economic outcomes.

Secondly, culture is difficult to distinguish from other institutional factors within a country. Our empirical study is based on a single country which enables us to isolate the effect of culture, because the legal origins and the legal and political system as well as its economic or financial developments are held constant. Switzerland is an old stable and federally organized direct democracy which has a developed capital market, an open economy, and strong multinational corporations. It is therefore likely that corporate governance follows culture, and not vice versa. Furthermore, in contrast to the United States, where state law can significantly differ between federated states and firms can choose corporate law by selecting the state in which they wish to be incorporated (e.g., Delaware, see Daines 2001), Swiss federal law fully defines corporate law throughout Switzerland. ${ }^{4}$

Thirdly, culture is rarely used as a determinant of corporate governance practices in empirical studies. Mostly, the effect of culture has been investigated on various other economic outcomes. In addition to ownership structure, we use the structure of the board of directors and the boards' composition to investigate differences in corporate governance across cultures. The board is an essential component of corporate governance (see Demb and Neubauer 1992). As a notable exception, Li

\footnotetext{
${ }^{4}$ Cantonal (state) law differs in some cases (e.g., tax law) and law enforcement is usually delegated to Switzerland's 26 cantons. The Securities Exchange Act (SEC) of 1934 is an example of a federal law in the United States.
} 
and Harrison (2008) use Hofstede's measures to examine the effect of culture on board independence and CEO duality. Licht (2001) argues that some factors such as the mandatory two-tier board structure cannot be investigated owing to a limited number of countries where they exist (e.g., Germany and The Netherlands) and a lack of variation in board structure due to its mandatory nature, thereby preventing any meaningful empirical analyses. We, however, are able to investigate this feature, because both board structures (one-tier and two-tier) are allowed by law and are equally prevalent in Switzerland.

This paper is organized as follows: Sect. 2 reviews the relevant literature and develops hypotheses. Section 3 describes the data and the variables, and the empirical analysis is presented in Sect. 4. Section 5 concludes.

\section{Theory and Hypotheses}

\subsection{Institutions, Culture, and Corporate Governance}

Diversity in corporate governance regimes is often explained by law and finance theory. It has been argued that corporate laws, and thus also corporate governance regimes, are determined by the fundamental principles that underlie their respective legal systems (e.g., civil or common law) (see e.g., La Porta et al. 1998, 1999a, 2000). Differences in corporate governance structures, notably ownership structures, are seen as a consequence of the origins of their legal system. This affiliation is especially evident in the case of British common law or French civil law. It is argued that the historico-cultural foundation of a country's legal system determines its subsequent corporate governance structures.

At least, in the aftermath of the corporate failures, fraud, and accounting scandals and the Asian Crisis which occurred around 2000, corporate governance reforms have become a major topic around the world. Denis and McConnell (2003) find some converging tendencies across jurisdictions (see also Hansmann and Kraakman 2000). However, firm-specific factors hamper the adoption of so-called best practices in corporate governance. Bebchuk and Roe (1999) argue that corporate governance is path-dependent and persistence in the form of corporate governance is determined by the country's initial or historical environment (see also Roe 1999; Rajan and Zingales 2003). Aguilera and Jackson (2003) contend that best practices are adapted and lead to distinct hybrid corporate governance systems. This development is driven by the cross-border interactions of economic actors (e.g., institutional shareholders). Khanna et al. (2006) find evidence that corporate governance laws between economically interdependent countries converge, but that corporate governance practices do not. Thus, although globalization has led to some convergence in corporate governance standards, corporate governance practices still differ around the world, and while the institutional environment of a country is important, it cannot sufficiently explain the persistence of corporate governance systems around the world.

Corporate governance systems evolve in line with their cultural and historical settings; they also develop in response to shareholder structures and the capital 
market environment (Hopt and Leyens 2004). Culture results from and affects behaviours and values, and is therefore likely to affect political regimes, the legal system and norms, corporate goals and values, and consequently corporate finance and governance (see Lüpold and Schnyder 2009; Daniel et al. 2012).

It is therefore obvious for researchers to include culture in their analyses on corporate finance and governance (see; Bebchuk and Roe 1999; Clarke and dela Rama 2006; Aguilera and Jackson 2010; Daniel et al. 2012). As a result, culture has been analyzed as a determinant of various economic outcomes. It has been associated with economic growth (Franke et al. 1991), economic development (Glahe and Vohries 1989), financial intermediation (Aggarwal and Goodell 2010), international capital flows (Siegel et al. 2011), capital structure (Chui et al. 2002), the firm's choice of entry (Tihanyi et al. 2005; Slangen and van Tulder 2009), financial development (Beck et al. 2003), government quality (La Porta et al. 1999b), and life insurance consumption (Beck and Webb 2003).

Some studies investigate culture as a determinant of corporate governance with regard to investor protection (Stulz and Williamson 2003), board of directors (Li and Harrison 2008), or mergers and acquisitions (Stahl and Voigt 2008). Dyck and Zingales (2004) show that (minority) shareholder protection, measured by the level of private benefits of control, is also affected by cultural norms. Shareholders fear negative public opinion and reputation costs if the media uncover bad shareholder behavior. Despite these notable exceptions, culture is often neglected in comparative studies on corporate governance (see Aguilera and Jackson 2010).

The measurement of culture presents two main challenges. Firstly, because culture is often identified at a country-level, and is measured together with other national (institutional) characteristics (e.g., the respective legal system), it is analytically difficult to isolate cultural-specific effects. Furthermore, culture is often viewed as a national factor and intra-country cultural heterogeneity is therefore ignored. And secondly, there are no clear variables that constitute culture and that are observable.

Buck and Shahrim (2005) study the effect of national culture on governance systems, namely the Anglo-American versus the Germanic system. Specifically, they describe the process of introducing a typical element of U.S. corporate governance in Germany: executive stock option programs. The process of introducing these programs in Germany was different from that in America, as the local institutional context and the boundaries of Germanic welfare capitalism have been given due consideration. Similarly, Yoshikawa et al. (2007) show that the introduction of some Anglo-American corporate governance practices in Japan was subjected to debate at firm and at institutional level, which resulted in Japanese firms adapting them to suit the limits of the country's context. Both of these case studies explain how governance practices evolve as hybrid systems, displaying elements of path dependence and convergence.

Hofstede's cultural dimensions theory has been widely used as a measure of culture and is well established in the international management literature. Other studies have proxied culture by more easily observable characteristics, namely language and religion. For instance, Stulz and Williamson (2003) underline the importance of culture with regard to investor protection issues, in particular, and 
finance, in general, arguing that a country's values depend on its culture (e.g., the ethos of levying interest on loans), that culture affects institutions (e.g., the legal system and property rights), and the allocation of resources (e.g., church spending). Having investigated 49 countries, they show that religion is a better predictor of investor protection than language.

\subsubsection{Language}

Hofstede (1980) considers language to be the most important and recognizable element of culture, and assumes that people speaking the same language within a specific territory share a common culture. Stulz and Williamson (2003) suggest that a common language facilitates the exchange of information, and Grinblatt and Keloharju (2001) also identified the association between separate languages and cultural effects. In fact, countries which form cultural clusters are often countries that share the same primary language or belong to the same language family (e.g., English, French, Spanish, and German) (see Ronen and Shenkar 1985, for a survey). While there are sufficient grounds to assume that language is a satisfactory proxy for culture, very often a language is also associated with particular institutional features and a specific religion. Interestingly, Chakrabarti et al. (2008) find that language, religion, and legal origins are highly correlated with Hofstede's cultural measures. Focusing on governance norms and laws, Licht et al. (2007) and Siegel et al. (2011) find empirical evidence confirming the relevance of Schwartz's and Hofstede's cultural dimension of hierarchy. Several observers have suggested that the French are inclined to accept hierarchical structures and centralized authority in contrast to Germans who are more egalitarian and prefer decentralization (see Hofstede 1980; Bebchuk and Roe 1999; Licht 2001). According to Hofstede's (2013) cultural dimensions, the French-speaking Swiss follow the French characterization and display a higher power distance score than German-speaking Swiss (see Table 11 in the Appendix).

\subsubsection{Religion}

Religion is another important expression of culture and a relevant factor that might explain the values, norms, and beliefs of people (see Williamson 2000). In its different guises, religion gives society rules for behavioral relationships (see e.g., La Porta et al. 1999b; Stulz and Williamson 2003). Most prominently, Weber (1930) argues that the work ethic of Protestants (compared to Catholics) is an immensely important factor in explaining economic development. According to Weber (1930), the Calvinist Reformation was crucial for the development of capitalism and its institutions, because Protestant theology fosters hard work and prepared the way for capitalist industrialization. ${ }^{5}$ Several studies empirically document that religion has an effect on economic performance (Glahe and Vohries 1989; Noland 2005), the

\footnotetext{
5 As a matter of fact, many French Protestant Huguenots fled from France and established the watchmaking industry in the Swiss Jura mountains.
} 
level of creditor rights (Stulz and Williamson 2003), the quality of government (La Porta et al. 1999b), and corporate decisions (Hilary and Hui 2009).

However, Becker and Woessmann (2009) identify the rate of literacy as the reason for higher economic prosperity in Protestant societies. There is strong empirical evidence that beliefs (especially trust), values and attitudes associated with religion, rather than religion itself, affect economic outcomes (see La Porta et al. 1997; Barro and McCleary 2003; Guiso et al. 2006; Arrunada 2010; Hayward and Kemmelmeier 2011). Protestants exhibit a higher level of trust in contrast to Catholics, which promotes trade and thereby economic development (La Porta et al. 1997; Glaeser and Glendon 1998; Guiso et al. 2006). In terms of transaction cost theory, trust can be considered as lowering transaction costs through reliance on the market price mechanism, instead of incurring increased costs through having to trade within an organization's hierarchy.

Religion and trust are therefore also related to organizational issues. Stulz and Williamson (2003) contend that the Calvinist Reformation promoted decentralization and the creation of multiple churches, and aimed to guard against concentrations of power. In contrast, Roman Catholicism, which is recognized as a religion whose congregations place their trust in people "who know more", has a centralized hierarchical structure with the Pope as its authoritative head (Levine 1979; La Porta et al. 1999b; Stulz and Williamson 2003, p. 319). The strong adherence that Roman Catholics are noted for having towards the hierarchical organization of their church and its apex of authority is thought to reduce their liaison with broader society (see Putnam 1993; La Porta et al. 1997). The cultural acceptance of hierarchical institutions, which in linking levels of authority nevertheless divide and separate them, is conceptually represented as being 'vertical'. This conceptualization of a vertical organizational structure is also represented by Hofstede's indicator power distance. Research identifies Roman Catholics as having a higher power distance score (greater tolerance for hierarchy) than Protestants (see Tang and Koveos 2008).

\subsection{Hypotheses}

Corporate governance aims to mitigate potential conflicts between managers or controlling shareholders and (minority) shareholders. The distribution of power within a corporation plays an important role in determining the nature of these different interrelationships. Religious or language groups share certain values which are likely to determine the form of corporate governance that is adopted by the firms. ${ }^{6}$ Two important features of corporate governance are the board of directors and the ownership structure. However, culture, which is multi-faceted, may affect corporate governance through different channels. For instance, features of culture (e.g., individualism) affect economic outcomes through institutional arrangements (e.g., education) which are favored by specific cultural values (e.g., Protestantism). In addition, cultural characteristics and institutional features often appear simultaneously (e.g., English and common law origin or French and civil law origin). The

\footnotetext{
${ }^{6}$ In democracies, the governance of the state is characterized by a separation of powers between the legislature, the executive, and the judiciary.
} 
literature on culture shows that there are significant differences along the dimensions of values. Based on his definitions, Hofstede characterizes the German-speaking people's character as being independent and skeptical towards a concentration of power, and the French or Swiss-French character as tending to tolerate hierarchical structures and strong leaders. ${ }^{7}$ France and Germany, the countries which are mostly associated with the French and German language, have different types of corporate governance regimes (see La Porta et al. 2000). Goyer (2006) perceives cultural differences between French and Germans in terms of their work ethic. Germans are more likely to share authority with their work force, while French organizations are more hierarchical. Hence, the different systems of value in the French and in the German cultural environment have led (potentially via legal rules) to different corporate governance structures. The French have a tendency to tolerate hierarchies and the concentration of power, while Germans tend to separate responsibilities. Similarly, Roman Catholics are described as having a significantly higher power distance score than Protestants who are associated with a preference of decentralization.

\subsubsection{One-Tier versus Two-Tier Boards}

The distribution of power and therefore the hierarchical organization of a corporation are especially apparent in the structure of the board of directors. Boards can be classified broadly as two-tier (dual) boards or one-tier (unitary) boards (see Douma 1997; Jungmann 2006). In the former case, each board has a clearly separate function, the one supervisory and the other executive. The supervisory board appoints and monitors the management (executive) board, and oversees its compliance with the law and the articles of incorporation. In the latter case, the board (or part of it, e.g. a delegate, CEO, or committee) also manages daily business. Hence, one-tier boards consolidate the functions of control and decision management.

In practice, board structures between Germany and France differ substantially, and reflect these countries' cultural values. The traditional board structure in France is one-tiered and therefore consists of executive (i.e., full-time employees with internal know-how) and non-executive directors. These boards are commonly directed by a strong leader who combines both functions of CEO and chairman ("président-directeur-générale" or "PDG") and who, hence, has extensive decisionpower (Hopt and Leyens 2004; Storck 2004; Millet-Reyes and Zhao 2010). ${ }^{8}$ In contrast, in Germany (and Austria), supervisory and executive tasks are separated

\footnotetext{
7 These characterizations are provided by Hofstede (2013) (http://geert-hofstede.com). Hofstede's basic framework measures cross-cultural differences assigned to four dimensions of national culture (power distance, uncertainty avoidance, individualism, and masculinity). Here, it should be noted that both the Swiss-Germans and the Swiss-French share an equally individualistic character (in contrast to collectivist), both believe in competition as a valid means to achieve merited job promotions (believed to a lesser extent in French-speaking Switzerland), and share a preference for avoiding uncertainty (more so in the French-speaking areas).

${ }^{8}$ Since 2001, French firms have been able to choose between a one-tier board structure ("conseil d'administration") and a two-tier structure ("conseil de surveillance" and "directoire"); nevertheless, only $23 \%$ of French firms have opted for the two-tier board structure (Heidrick and Struggles 2011).
} 
by law and are allocated, respectively, to a supervisory board and a management board, which establishes a clear division of responsibilities (two-tier board structure). In other words, no executive manager is active on the board of directors, as this board has a purely supervisory function.

Swiss law gives all corporate fiduciary duties to one board of directors (one-tier), however, the board is free to delegate (transferable) duties relating to daily business to one or more board members (a delegate or an executive committee) or a separate management team (in the sense of a two-tier board structure). Swiss law enables firms to adopt the structure which is best suited to their corporate goals, and because the board constitutes itself, it can fairly be assumed that there is a cultural impact on the board's structure. It is assumed that the cultural values which are embedded in specific languages and religions are clearly manifested in the way corporate structures allocate power. Because a corporate structure and the way it distributes power are linked to values which are culturally carried by language and religion, it may be hypothesized that there should be a higher incidence of corporations which have hierarchical corporate structures in Swiss-French areas and Roman Catholic cantons (states).

Hypothesis 1: One-tier boards (in contrast to two-tier boards) are more prevalent in Swiss-French areas relative to Swiss-German areas and in Roman Catholic cantons relative to Protestant cantons.

\subsubsection{Board Composition}

Culture affects the level of trust which is closely related to both language and religion. Guiso et al. (2009) find significant differences in the capacity for trust between managers in Europe which they ascribe to different cultural heritages and home-country bias. In behavioral finance, home or familiarity bias has also been observed with respect to stock ownership. Investors tend to invest in firms that they are familiar with and share the same language and culture with (see Grinblatt and Keloharju 2001; Becker et al. 2008; Kang and Kim 2008). More generally, we observe, for example, that labor mobility within the European Union is hampered by language and culture (see Nickell 1997). People tend to migrate within familiar environments. ${ }^{9}$

Board members are elected by their shareholders, but typically they are selected by the board itself. Either way, the election is potentially affected by the cultural stance that is expected to be promoted by the candidate. Directors may be elected because they share the same culture. Because it is difficult to identify a director's religion and find out how he or she is practicing religion, the cultural similarity of directors is measured using the primary language they speak.

Hypothesis 2: Boards are composed by directors who share the same primary language with the firm's headquarters' location.

\footnotetext{
9 For instance, there are relatively more Germans in the German-speaking towns of Basel and Zurich, and there are relatively more French in the French-speaking town of Geneva (see Table 12 in "Appendix").
} 


\subsubsection{Ownership Structure and Multiple Classes of Equity}

Cross-country heterogeneity in ownership structures is one of the central topics in comparative corporate governance studies (Denis and McConnell 2003; Aguilera and Jackson 2010). Ownership structure is an important factor in corporate governance and shapes the agency relationships within firms. While in Anglo-Saxon countries corporate ownership is dispersed and corporations are mostly widely held, in the rest of the world, including Switzerland, France, and Germany, many firms are controlled by one important shareholder, e.g., a family (see La Porta et al. 1999a; Faccio and Lang 2002). Attempts to explain ownership concentrations around the world have argued that self-regulation of stock exchanges (Coffee 2001), initial ownership structures and the pressure of interest groups (Bebchuk and Roe 1999), skepticism towards the concentration of power on Wall Street (Roe 1991), new corporate laws introduced in the 1930s (Gillan and Starks 2007; Lüpold and Schnyder 2009), or economic actors and merger waves (Aguilera and Jackson 2003) have led to changes in ownership structures. Combining law and culture, Bozec et al. (2008) and Boubraki et al. (2011) show that Canadian firms in the Frenchspeaking province of Québec have a higher ownership concentration than firms in the other (English-speaking) provinces. However, Québec firms, unlike Swiss firms, can choose to incorporate under Canadian federal law (based on common law) or under the Québec provincial law (based on civil law). ${ }^{10}$ They reveal that incorporation under the civil law regime is significantly positively related to the ownership concentration. Therefore, they confirm that the legal system is an important determinant of ownership concentration. This leaves doubt as to whether culture or legal rules are more important in explaining ownership structures. Licht (2001) argues that the Western European tendency to support egalitarianism opposes the prevalence of blockholding. Conversely, concentrated ownership could be explained by uncertainty avoidance and less stock ownership held by the general population. Interestingly, Guiso et al. (2003) find that Catholics value private ownership and competition more than Protestants. The tendency to accept strong leadership is likely to be positively related to cumulated voting rights. Furthermore, a tolerance for hierarchical structures and risk avoidance are likely to lead to equity structures that decouple voting from cash flow rights and the associated financial risks.

Hypothesis 3a: Ownership concentration is higher in Swiss-French areas relative to Swiss-German areas and in Roman Catholic cantons relative to Protestant cantons.

Hypothesis 3b: Multiple-class firms are more prevalent in Swiss-French areas relative to Swiss-German areas and in Roman Catholic cantons relative to Protestant cantons.

\footnotetext{
10 All three countries' (Switzerland, Germany, and France) legal system is based on civil law (in contrast to common law).
} 


\section{Data and Definition of Variables}

Switzerland provides an excellent case for studying the effects of culture on corporate governance, because Swiss firms exhibit two important cultural characteristics: language and religion. ${ }^{11}$ In particular, all firms are subject to the same institutional environment; notably, one (federal) corporate law that applies for all firms. Swiss corporate law leaves substantial leeway to firms regarding corporate governance. For example, the law allows all firms to decide how to structure their boards (i.e., one-tier or two-tiers). In our literature review, we document potential differences in attitudes towards a concentration of power between Swiss-Germans and Swiss-French, and Roman Catholics and Protestants. Both the Swiss-French and Roman Catholics tend to tolerate a concentration of power, while the SwissGermans and Protestants tend to prefer a dispersion of power. We examine the effect of culture on corporate governance by comparing firms incorporated in the German- and the French-speaking part of Switzerland, as well as in Roman Catholic and Protestant cantons. We use a $t$ test for the comparison of the mean values and a Wilcoxon rank sum-test of the equality of medians to compare corporate governance. ${ }^{12}$ In addition, we use Logit regressions for our binary board and equity structure variables and Ordinary Least Squares (OLS) regressions for our board composition and ownership variables controlling for other firm characteristics.

\subsection{The Swiss Confederation}

Using culture to explain different economic outcomes is appealing, but difficult to investigate. In our case, Switzerland provides two language regions (65\% of the Swiss are German-speaking and $18 \%$ are French-speaking) and two different religions (42\% of the Swiss are Roman Catholic and $35 \%$ are Protestant). ${ }^{13}$ Swiss cultures "are strongly influenced by the cultures of Switzerland's neighbors, France, Germany, and Italy". ${ }^{14}$ Mayer (1951) contends that languages and religions define the cultural pluralism of Switzerland.

Switzerland is an old and stable (direct) democracy and confederation, consisting of 26 cantons. The foundation of Switzerland in 1291 was the consequence of a group of communities' desire for independence and security against enemies and foreign control. The country has been a federal republic since 1848. As a result of this common cause, the Swiss grew together and created a "national equilibrium"

\footnotetext{
11 Firms can thus be defined as Swiss-French and Protestant, Swiss-French and Roman Catholic, SwissGerman and Protestant or Swiss-German and Roman Catholic.

12 The two-sample Wilcoxon rank sum-test (or Mann-Whitney-test or U-test) verifies the null hypothesis that the true location shift of two distributions is equal to zero. Following a number of other studies, we verify the equality of medians using this test (e.g., Fahlenbrach et al. 2010).

13 CIA-The World Factbook: https://www.cia.gov/library/publications/the-world-factbook/index.html (access on 12/09/2012).

14 Official webpage of the Federal Department of Foreign Affairs: http://www.eda.admin.ch/eda/en/ home/doc/infoch/chcul.html (access on 12/09/2012).
} 
formed by cultural differences (Mayer 1951). Switzerland is often referred to as a country forged by the will of the people ("Willensnation").

The federal structure counters power concentration at the highest federal level. There are basically three levels of checks and balances (federal, cantonal, and community). As a result of these hurdles, significant political changes are typically rare. The principle of subsidiarity and the direct democracy are the two most important elements of politics in Switzerland.

In relation to language, almost all listed corporations are located either in the German-speaking part or in the French-speaking part of Switzerland (see Footnote 1). The linguistic demarcation line is referred to as the "Röschtigraben" ${ }^{15}$, which runs along the valley of the river Saane near the bilingual town of Freiburg/ Fribourg. Swiss-German ethnic origins stem from the Alemanni (a Germanic tribe), while the Swiss-French are primarily descendants of Romanized Celts and Burgundians (a Germanic tribe): language thus proxies well for ethnicity in Switzerland (see Dorn et al. 2008). Hofstede characterizes the Swiss-German character as being independent and skeptical towards a concentration of power and the Swiss-French character ("very similar to France") as being open to hierarchical structures and strong leaders. Linguistic affiliation also affects the duration of unemployment and voting behavior (Dorn et al. 2008; Brügger et al. 2009).

Religion in Switzerland is not affected by the language divide, but can instead be differentiated between rural and urban areas. In rural areas (e.g., Eastern and Central Switzerland or the Alps) Roman Catholicism is predominant. The four major Swiss cities (Zurich, Geneva, Basel, and the capital Berne) are all Protestant. Zurich and Geneva are also famous for being the domains of the renowned reformers, Zwingli and Calvin, respectively, who introduced the Protestant Church in the 16th century. ${ }^{16}$ The last civil war in Switzerland in 1847 resulted from a conflict between the conservative Roman Catholic cantons and the mostly Protestant liberal cantons and ended in the federal constitution of 1848. The federal constitution guarantees freedom of religion and conscience, and no significant conflicts have been noted since then. Weber (1930) argues that the Protestant work ethic is an important factor for economic activity. This may be one reason why Switzerland is home to a number of large multinational firms which cluster around the major cities. Examples include ABB, Novartis, Roche, and UBS (German-speaking region); and Adecco, Nestlé, Richemont, and SGS (French-speaking region). Furthermore, Swiss firms in general rely on large-scale exports and quite often produce worldwide, which is also a consequence of Switzerland's small home market. At least since the 1990s, Swiss corporate governance has been directed towards protecting shareholder interests (Wymeersch 1998; Lüpold and Schnyder 2009), as is the case in Anglo-Saxon countries.

\footnotetext{
15 "Röschti" is a famous Swiss potato dish. "Graben" is the German word for ditch.

16 Johannes Calvin's (1509-1564) doctrines were proclaimed from Geneva in the French-speaking part of Switzerland. At about the same time, another important reformer Ulrich Zwingli (1484-1531) was teaching in German-speaking Zurich.
} 


\subsection{Data}

We target all firms included in the Swiss Performance Index (SPI) from 2005 to 2009. The SPI is the main index of the SIX Swiss Exchange. In total, 18 firm-years from the Italian part of Switzerland (of which 2 firms/10 firm-years are utilities) are excluded from the analysis. We exclude regulated industries (utilities and banks) as well as financial services (see Booth et al. 2002). The corporate governance of firms in regulated industries is affected by various stakeholders (e.g., regulators or politicians). In addition, they are typically controlled by the state. Banks are obligated to have two-tier boards, and financial firms in general exhibit noncomparable corporate structures (e.g., grade of diversification, debt-to-assets ratio). Otherwise, all firms are subject to the same legal environment (e.g., corporate law, stock exchange regulation). Our final sample consists of 753 firm-years of which 631 firm-years (84\%) are Swiss-German and 122 firms-years (16\%) are SwissFrench. Of this total, 517 firm-years $(69 \%)$ stem from Protestant cantons and 236 (31\%) from Roman Catholic cantons. Information about the corporations' headquarters and the year of incorporation has been obtained from the commercial register. Information about boards, their directors, and ownership has been gathered from annual reports. In some cases, additional information about directors has been obtained from BoardEx and newspapers. The financial data is from Thomson Reuter Datastream.

\subsection{Definition of Variables}

\subsubsection{Culture Variables}

We use two proxies for culture: language and religion. Both variables are identified on the basis of the firm's headquarters. Swiss-French area equals 1 if the firm is located in the French-speaking part of Switzerland, and 0 otherwise (i.e. Germanspeaking). Roman Catholic canton equals 1 if the firm is located in a mainly Roman Catholic state, and 0 otherwise (i.e., Protestant). We define cantons as being Roman Catholic where "All Saints' Day" is a bank holiday.

\subsubsection{Corporate Governance Variables}

We focus on two main corporate governance mechanisms: board structure and ownership structure. Both are important control devices in a corporation and are the subject of numerous studies. Board structure has two characteristics: one-tier board equals 1 if the board consists of at least one executive director, and 0 otherwise (two-tier board). German-speaking/French-speaking measures the fraction of German- or French-speaking directors and accounts for board composition.

The ownership structure is measured using the cumulated voting rights of all large shareholders. Large shareholders have more than $3 \%$ of the voting rights. ${ }^{17}$

\footnotetext{
17 In 2005, the threshold for "significant" (large) shareholders was $5 \%$. However, this change had no particular influence on cumulated voting rights in any of the cultural areas.
} 
Multiple classes of equity is a dummy variable that takes the value of 1 if the firm has more than one class of equity outstanding, and 0 otherwise. The deviation from one share-one class typically leads to a situation where one shareholder can dominate co-shareholders.

\subsubsection{Control Variables}

Empirical studies have shown that corporate governance structure is affected by the business' environment (see, e.g., Boone et al. 2007; Coles et al. 2008; Linck et al. 2008; Lehn et al. 2009). For instance, younger, smaller, focused firms with higher sales growth and which potentially operate in a more volatile environment may benefit from boards that are composed by insiders because they can more easily transmit information to non-executive outsiders. We regard corporate governance as a function of a firm's cultural, regulatory and operational environment. We therefore include four control variables that we regard as exogenous determinants of corporate governance: firm age, sales growth, diversified, and firm size. In addition, we employ industry fixed effects for three different industries.

Firm age is the year of the firm's establishment minus the current year (plus 1). Following Black and Khanna (2007), sales growth is the geometric mean of annual sales growth over four periods, and firm size is the book value of total assets (total liabilities and the shareholder equity). We use logarithms for both firm age and firm size to account for skewness of the variables. Diversified is a dummy variable that takes on the value of 1 if the firm reports more than one business segment, and 0 otherwise. We include three dummy variables for healthcare, consumer, and industrials to account for industry effects.

\section{Analyses and Results}

\subsection{Summary Statistics and Correlation Matrix}

Table 1 presents summary statistics of the main variables in our analysis. Over all 3 years, $16.20 \%$ of all firms were located in the Swiss-French area. The proportion is $0.78 \%$-points higher in 2005 than in 2009. In the same period, $31.34 \%$ of all firms were located in Roman Catholic cantons, which increased from $30.56 \%$ in 2005 to $31.13 \%$ in 2009. Our corporate governance variables evolved more strongly over the period. About $56 \%$ of all boards were one-tiered in 2005, but only $51 \%$ in $2009 .{ }^{18}$ The cumulated voting rights increased notably from $40.86 \%$ in 2005 to $46.18 \%$ in 2009. This increase can be explained by new regulations introduced in 2007 that demand that shareholders with significant stockholdings of $3 \%$ instead of $5 \%$ disclose their holdings. In the sample, no firm changed its headquarters.

\footnotetext{
18 We investigated the 36 firms that changed their board structure (41 board changes) in 2005, 2007, and 2009. 24 board changes were from one-tier to two-tier and 17 from two-tier to one-tier. Only 3 board changes occurred in the Swiss-French area. Boards of the 15 newly listed firms were mostly one-tiered.
} 


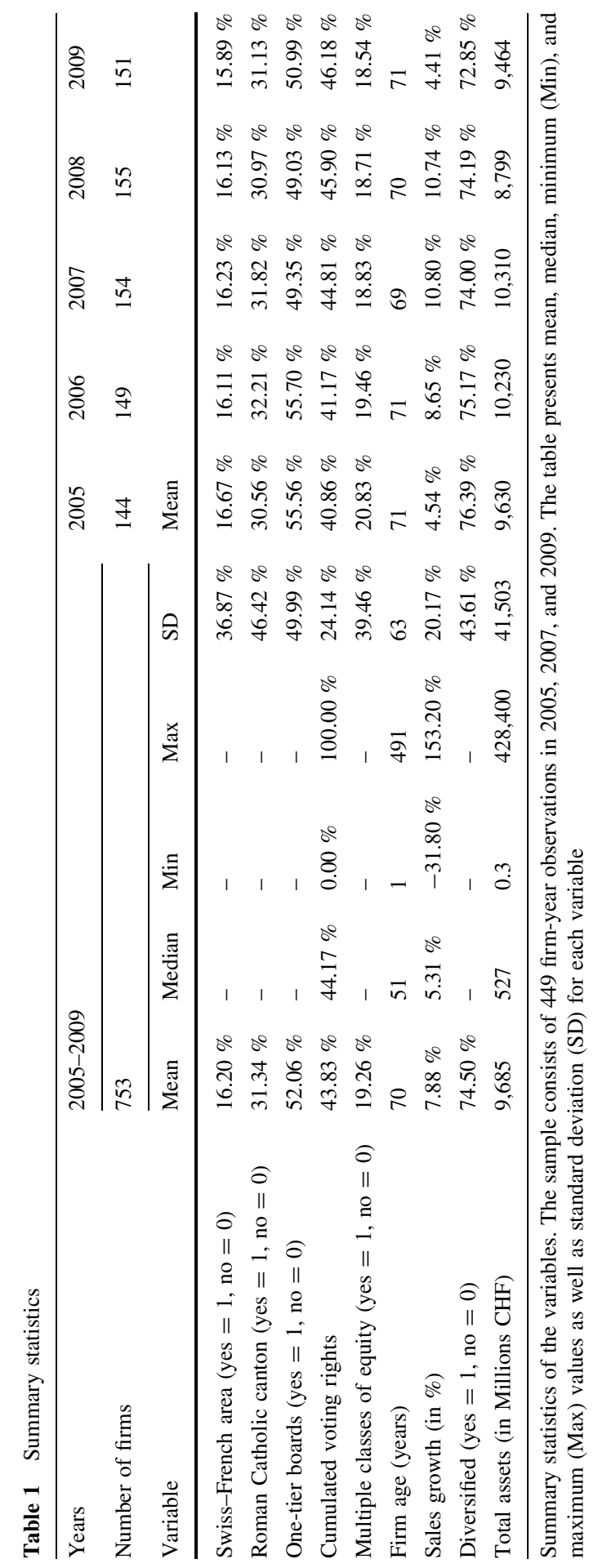


Table 2 presents results from Pearson's correlation matrix. A high correlation of over 0.7 , which — as a rule of thumb — would usually lead to a multicollinearity problem, is not observed. However, the analysis shows that firms in Swiss-French areas are less likely to be in Roman Catholic cantons, and firms in Swiss-French areas and Roman Catholic cantons are positively related with one-tier boards. In addition, Swiss-French firms and firms in Roman Catholic cantons are more likely to make use of multiple classes of equity.

\subsection{Is Culture a Determinant of Board Structure?}

We investigate the effect of culture on board structures using the fact that culture is likely to affect the propensity to accept hierarchical structures. Table 3 presents initial evidence on differences in board structure between boards in the four cultural areas. An important difference becomes evident. Boards in the Swiss-French area are more likely to be one-tiered. This difference is significant on the $1 \%$ level for both means and medians. However, this is not a result of the fact that the CEO and chairman positions are likely to be combined in the French-speaking region as the French PDG-model would suggest. Rather, the CEO is more likely to be present on the board as an ordinary board member. In addition, there are more executives (including the CEO) on the boards of Swiss-French firms. Similarly, boards in Roman Catholic cantons are more likely to be one-tiered and have a higher proportion of executive directors than boards in Protestant cantons.

However, the firms that operate in the cultural areas may have some common characteristics that affect board structure. Therefore, we have to account for factors other than culture that may affect the choice of the board structure. In Table 4, we estimate a Logit model of board structure $(1=$ one-tier board, $0=$ two-tier board $)$ using both Swiss-French area and Roman Catholic canton as explanatory variables and employ five control variables in addition to industry effects that are likely to influence board structure and may differ across our cultural proxies.

The analysis shows that firms in the French-speaking part of Switzerland and in Roman Catholic cantons are significantly more likely to have a one-tiered board structure (Column II). The two cultural variables increase the explanatory power of the models by almost $4 \%$ (4.6\%, Column I and $8.5 \%$, Column II). This result holds for most of the time period (Columns III to VII). In other words, SwissGerman boards and boards in Protestant cantons are more likely to be two-tiered. The boards are structured in the same way as in Germany. Power is separated into a supervisory and a management board. Therefore, we cannot reject Hypotheses 1 that one-tier boards are more prevalent in the French-speaking area and in Roman Catholic cantons. The cultural effect that both proxies are likely to accept hierarchical structures cannot be rejected.

The figures in Table 5 indicate that the compositions of the boards are likely to differ as a consequence of language barriers. There is a higher representation of French-speaking directors (French citizens and directors who have graduated from Swiss-French universities) on corporate boards in the Swiss-French area. Similarly, German-speaking directors (German or Austrian citizens and directors who have graduated from Swiss-German universities) are prevalent on Swiss-German boards. 


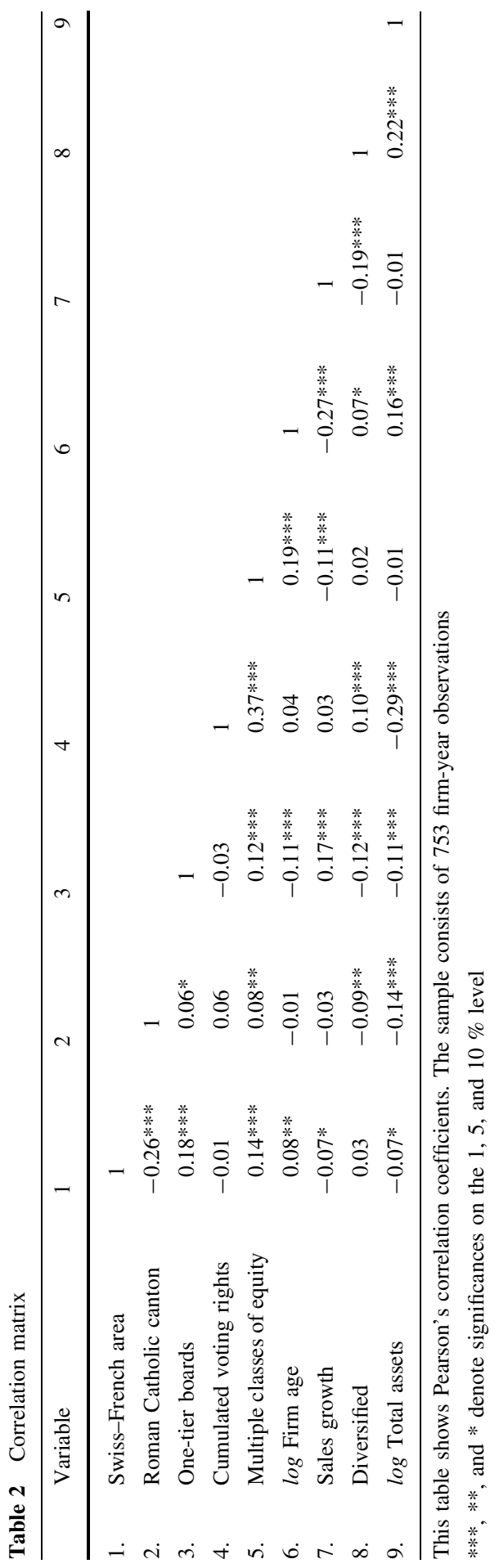




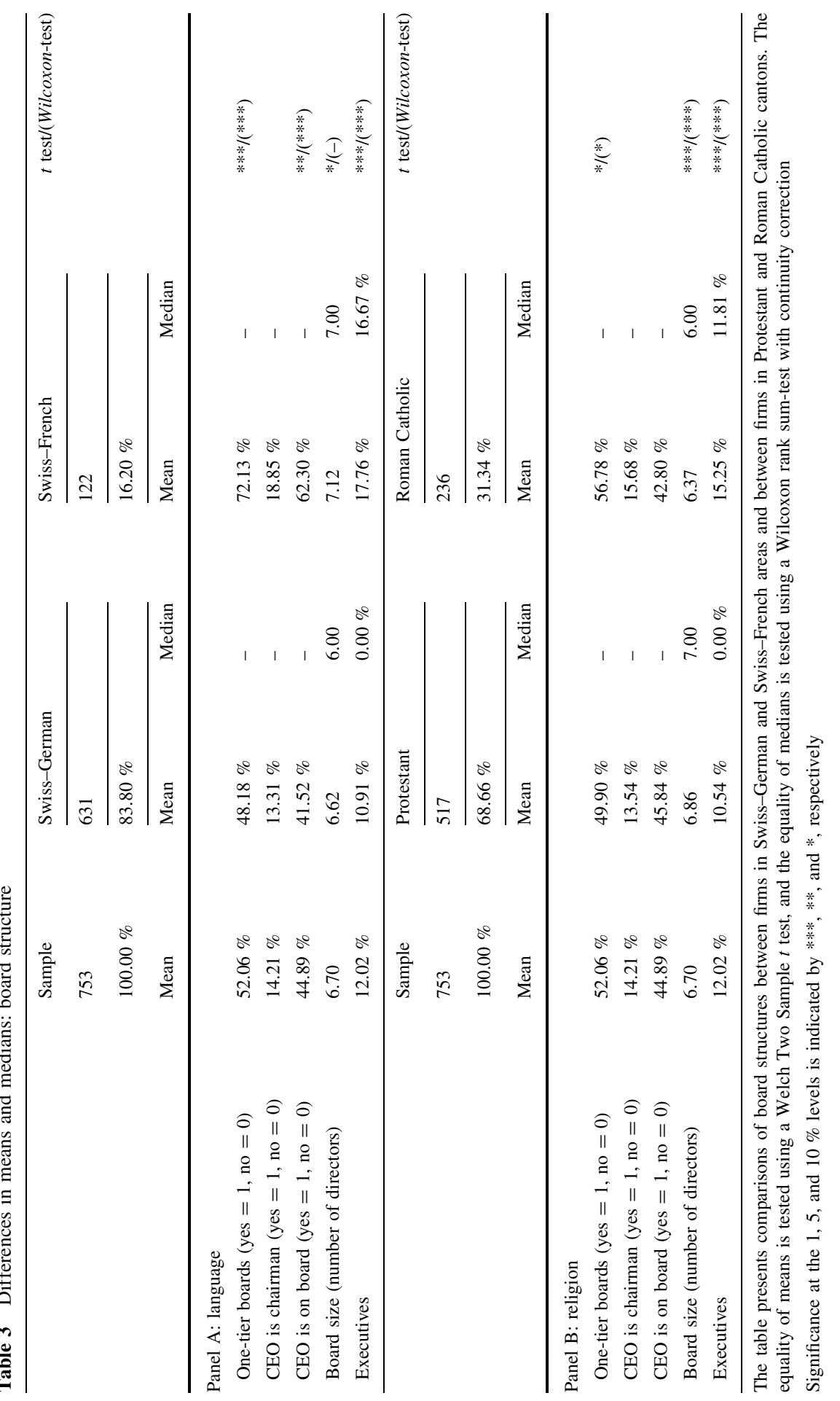


Interestingly, diversity (i.e., the fraction of women and foreigners) is almost identical in both linguistic regions, but lower in Roman Catholic cantons. It is very difficult to observe the religion of all board directors and whether they are practicing religion or not. However, the lower fraction of foreigners on boards in Roman Catholic cantons could be an indicator that trust plays a role in the selection of more familiar directors. In contrast, other more functional director characteristics (e.g., education) do not show consistent differences across the two language regions.

The results from Table 5 can be confirmed in regression models (Table 6) which include control variables for the nationality of shareholders. Hypotheses 2 cannot be rejected, because board composition differs in the two language regions. Germanspeaking directors are more prevalent on Swiss-German boards and Frenchspeaking directors are more prevalent on Swiss-French boards. This result is interesting, because in an increasingly globalized market where English is the predominant business language, language (and culture) may still play a role. Admittedly, the fact that a director is educated at a Swiss-French university does not entirely imply that he or she is French-speaking. For instance, German-speaking directors might have attended a Swiss-French university, and vice versa. However, evidence from Switzerland shows that students are attracted by the universities that are most familiar to them.

\subsection{Is Culture a Determinant of Ownership Structure?}

Ownership is the most frequently discussed mechanism in comparative corporate governance. Cross-country heterogeneity in corporate ownership has mainly been explained by differences in legal origin. In fact, the figures in Table 7 suggest that there are no differences in ownership structure across cultures. Swiss firms in general exhibit a rather high level of cumulated voting rights (around $44 \%$ ). However, there are tendencies that suggest a familiar (or local) bias (see Grinblatt and Keloharju 2001; Becker et al. 2008; Kang and Kim 2008). The Germans have a higher number voting rights in Swiss-German firms and the French a higher number of voting rights in Swiss-French firms. In addition, in the French-speaking part of Switzerland and in Roman Catholic cantons, multiple classes of equity are more prevalent than in the German-speaking part of Switzerland and in Protestant cantons. This ownership structure typically leads to more voting rights relative to cash flow rights.

We use ordinary least squares (OLS) and logit regression estimations to examine the cultural effect of language and religion on ownership structure in Tables 8 and 9.

As the results in Tables 8 and 9 show, we find no consistent significant results over all 5 years. In consequence, we reject Hypothesis $3 \mathrm{a}$ that ownership concentration is higher in the French-speaking part of Switzerland and in Roman Catholic cantons. In line with Boubraki et al. (2011), the legal system may be a more important determinant of ownership structure than culture. Multiple-class firms are more prevalent in Roman Catholic cantons relative to Protestant cantons. However, we also reject Hypothesis $3 \mathrm{~b}$ that firms in Roman Catholic cantons and 


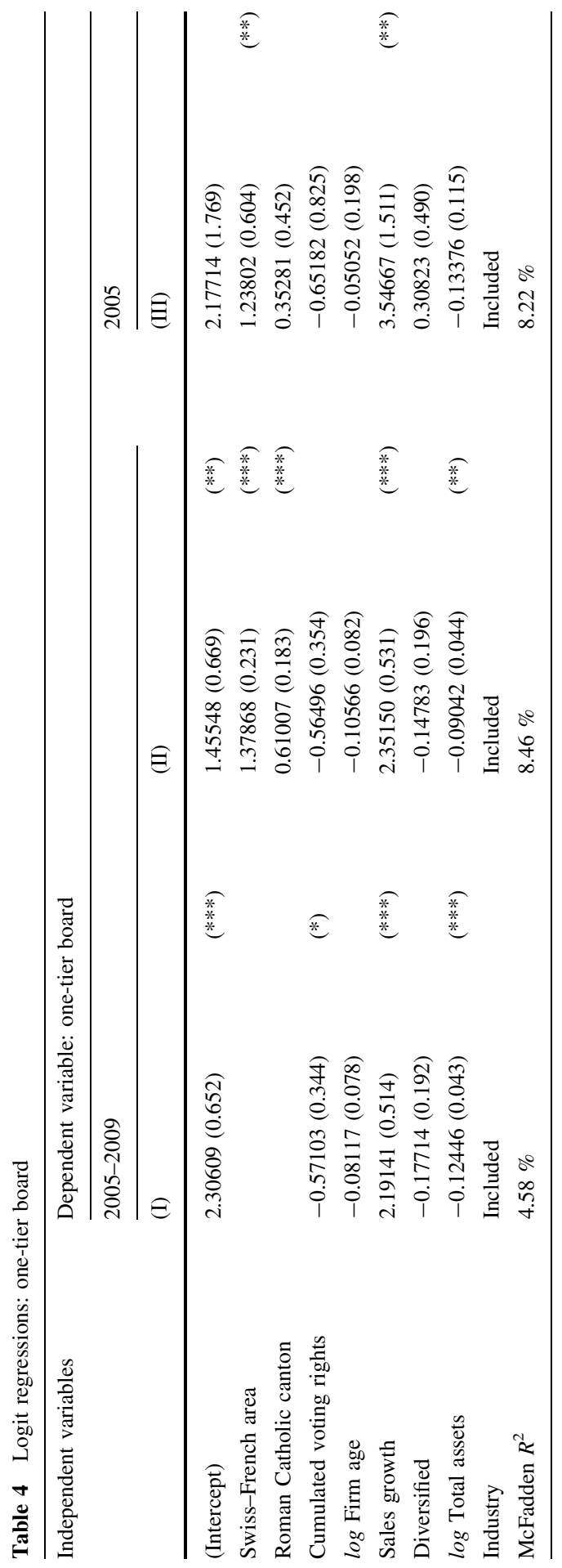




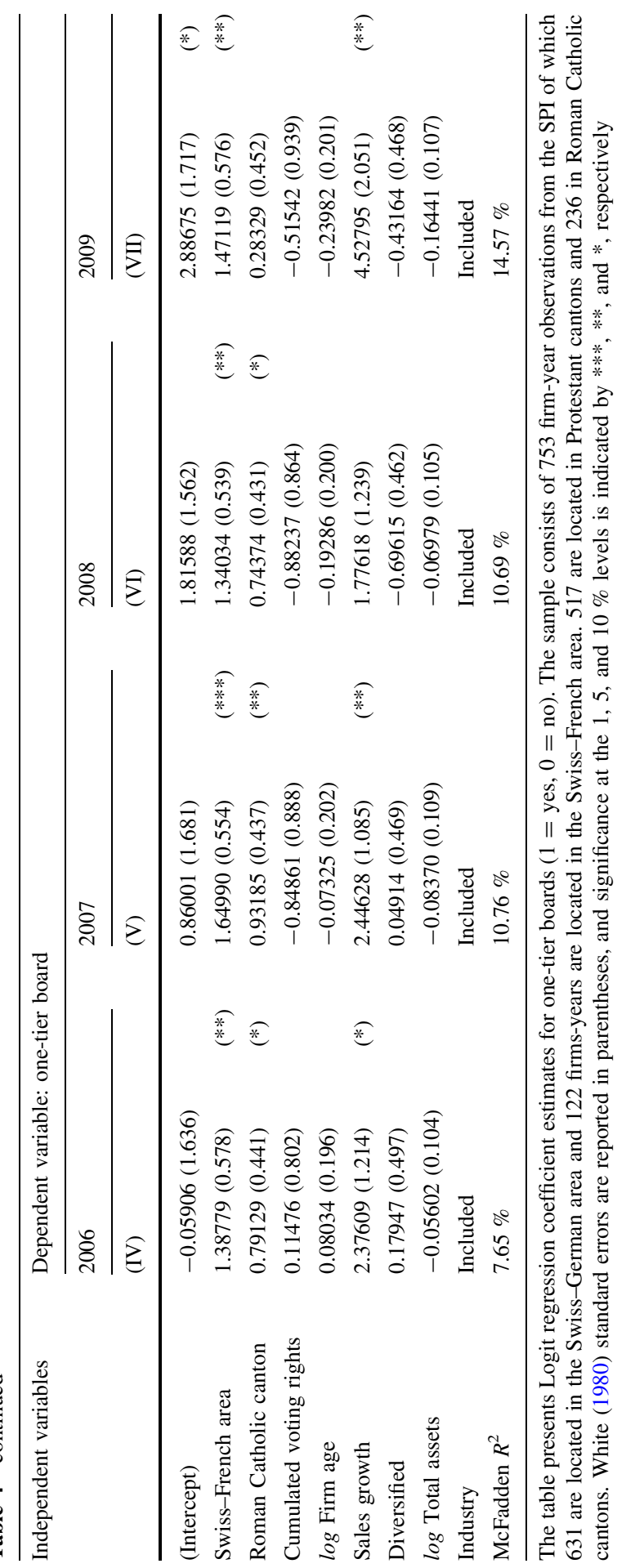


Swiss-French areas are more likely to have multiple-class equity structures because the results are not consistent over the whole period.

\subsection{Robustness}

Our models are not subject to multicollinearity as indicated by the correlation matrix (see Table 2) and the variance inflation factors for our regression models do not exceed 2. To mitigate the omnipresent threat of heteroskedasticity, we routinely estimated all our models using Huber-White's robust standard errors (White 1980). Endogeneity is often a problem in studies on corporate governance. Investigating the effect of language and religion on corporate governance, we assume that reverse causality is not a problem in our analysis. Since the variables that we use as proxies for culture are time-invariant, we must abandon the use of firm fixed effects, however, by including an array of potential control variables, we mitigate the problem of omitted variable bias.

As a robustness check, we analyze our models by including additional control variables that potentially affect corporate governance (see e.g., Coles et al. 2008; Linck et al. 2008): family-control is 1 if a firm is controlled by a family or a private person who owns $20 \%$ or more of voting rights (see Faccio and Lang 2002). Performance is measured using Tobin's Q, which is calculated as total assets plus market value of equity minus total equity divided by total assets which we use as an approximation of replacement value. Leverage is the ratio of the book value of debt to the book value of total assets. Furthermore, we include Beta as a proxy for a firm's risk and time fixed effects in our models. Table 10 shows that the additional control variables do not affect the results produced by our standard models at all. The results remain almost the same (This is equally true if we estimate every model per year).

\section{Conclusions}

Corporate governance deals with conflicts of interest within corporations. The corporation is the predominant form of legal structure that firms adopt around the world, while corporate governance practices differ. In this study, we investigate whether culture affects corporate governance using Switzerland as a particularly interesting case since within a single institutional setting, the country is both multilingual and multireligious. Specifically, we examine differences in corporate governance structures between the German-speaking part of Switzerland and the French-speaking part of Switzerland, as well as differences between Roman Catholic cantons and Protestant cantons (states).

The fact that both proxies for culture are measured within one nation allows us to isolate culture from other institutional factors. For instance, the legal system and the political system as well as their interaction have been proven to be important determinants of corporate governance at a country-level. In Europe, welfare capitalism, state influence and family ownership all affect corporate governance practices. These factors hamper results when comparing corporate governance 


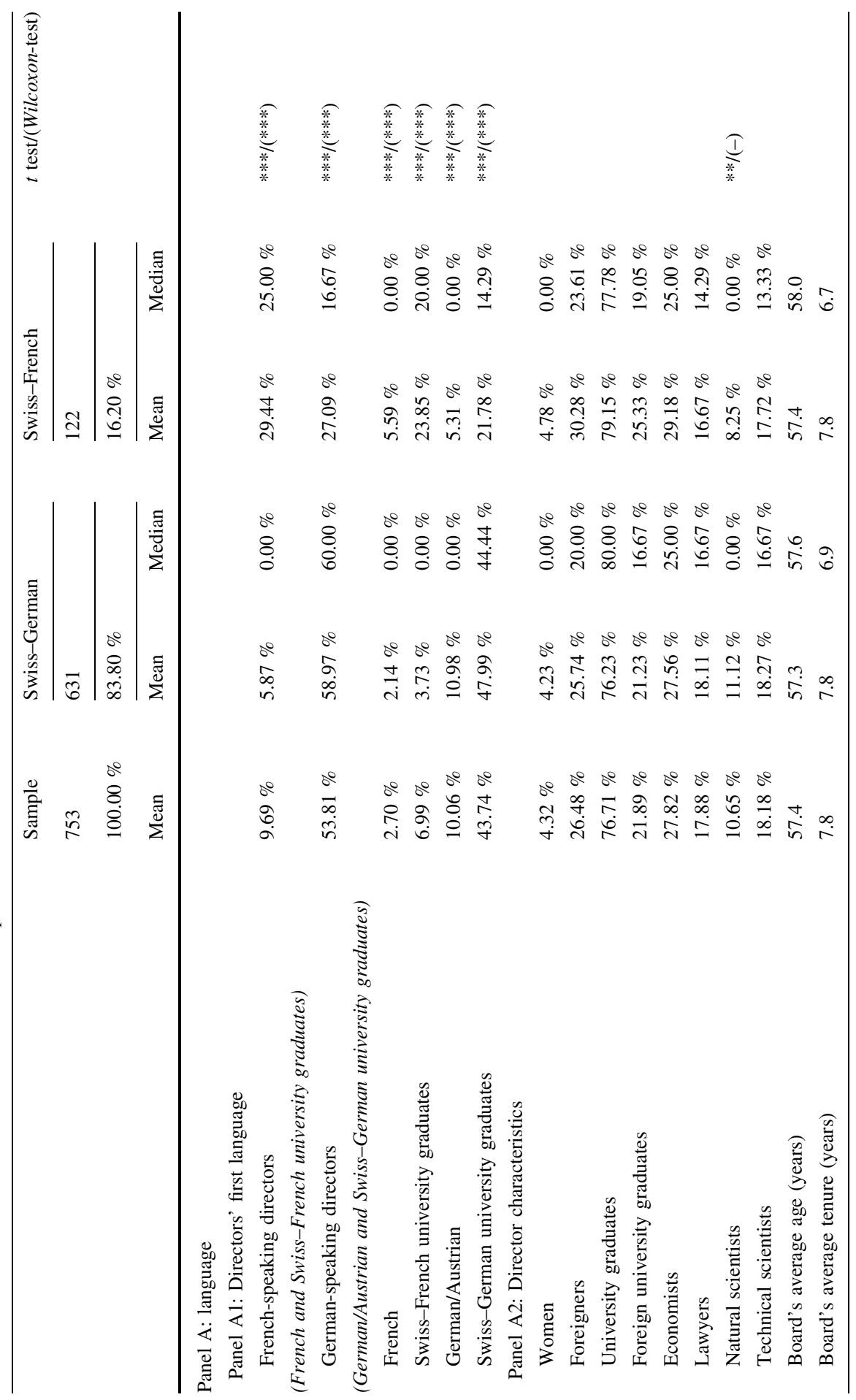




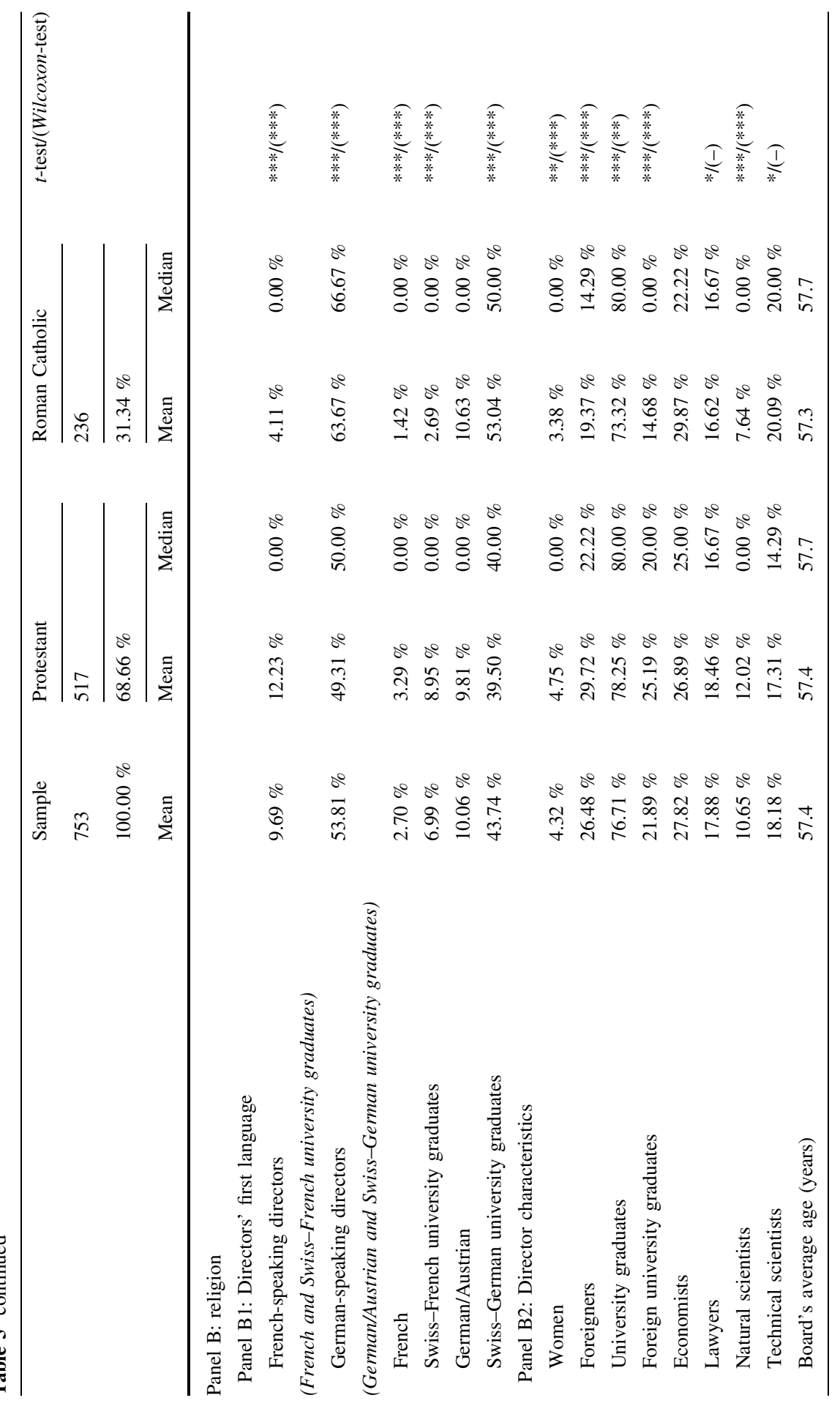




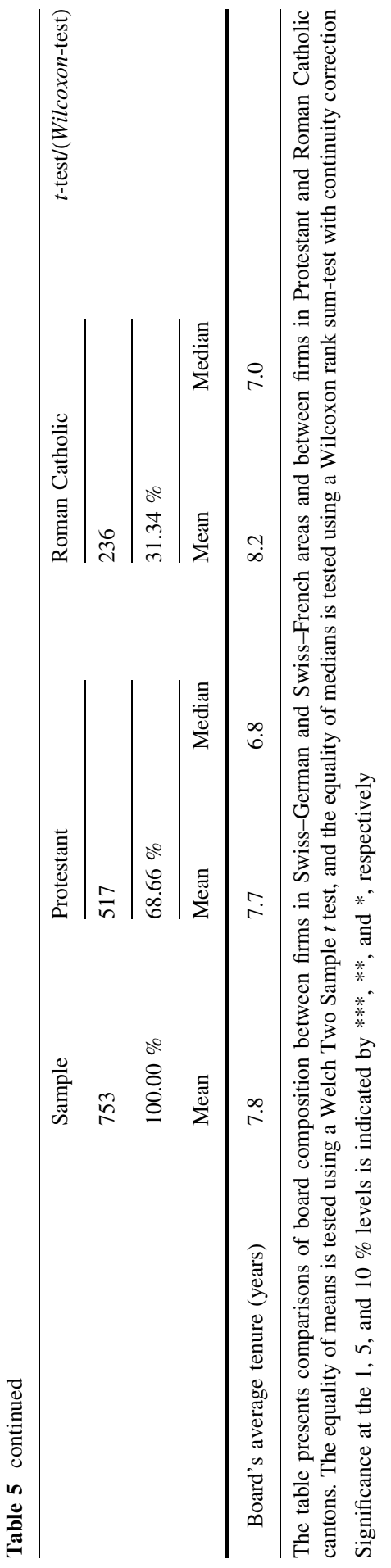


systems in cross-country studies. In Switzerland, all regions share one and the same federal corporate law. Also political decisions concerning corporate law influence firms only at a country-level (and not in their headquarters' locations). In addition, Swiss corporate law is rather flexible and allows firm-specific optimizations in corporate governance structures which may be influenced by culture.

Swiss-Germans and Swiss-French, Roman Catholics and Protestants have distinct values, beliefs, and norms. The four groups have different biases towards hierarchy. Particularly, within Hofstede's concept of cultural dimensions, the main difference between the culture of the Swiss-Germans and the Swiss-French is manifested in their scores on power distance which is related to hierarchy. In contrast to finance literature which is mainly concerned with risk aversion or uncertainty avoidance, we relate power distance to corporate governance structures. While the Swiss-Germans and Protestants are less hierarchical, the Swiss-French and Roman Catholics tend to tolerate hierarchical structures.

Our study shows that boards are very likely to be influenced by culture. Swiss-German boards and boards in Protestant cantons are commonly observed to have a two-tiered board structure. This type of board structure is also used in Germany. This structural feature, which strictly separates the supervisory board from the management board, assists in preventing the concentration of power that occurs in one-tier boards. In the Swiss-French area and in Roman Catholic cantons, one-tier boards are more prevalent, which necessarily results in concentrations of power. By confirming these observations, our study demonstrates that firms opt for board structures that correspond to their cultural identity. Furthermore, we find evidence that board composition is influenced by language. Directors are active in firms where they share a common first language which is also the regional language of the corporation's headquarters. This conjunction of cultural factors suggests that trust may play a role, as well as the fact that the (national) market for directors is segmented. In contrast to these factors, ownership concentration and the prevalence of multiple classes of equity are not consistently related to culture. Nevertheless, there is a tendency that Swiss-French firms have a lower level of cumulated voting rights, while firms in Roman Catholic cantons are more likely to have issued more than one class of equity.

While Hofstede (2013) provides statistical evidence on differences between the Swiss-Germans and the Swiss-French, our study shows that differences in corporate governance practices exist across cultures in Switzerland. An investigation of the effect of culture on business practices and corporate governance is important, since firms reflect the fact that they are governed, managed and run by people. Both practitioners and academics acknowledge the importance of culture in international business, trade and cross-border transactions. Similarly, regulators and legislators might be aware of the importance of culture for the implementation of specific corporate governance practices around the world. However, how and why culture affects corporate governance is less apparent. Furthermore, globalization has led to an awareness of national differences in the legal, institutional, and regulatory frameworks underpinning corporate governance systems. 


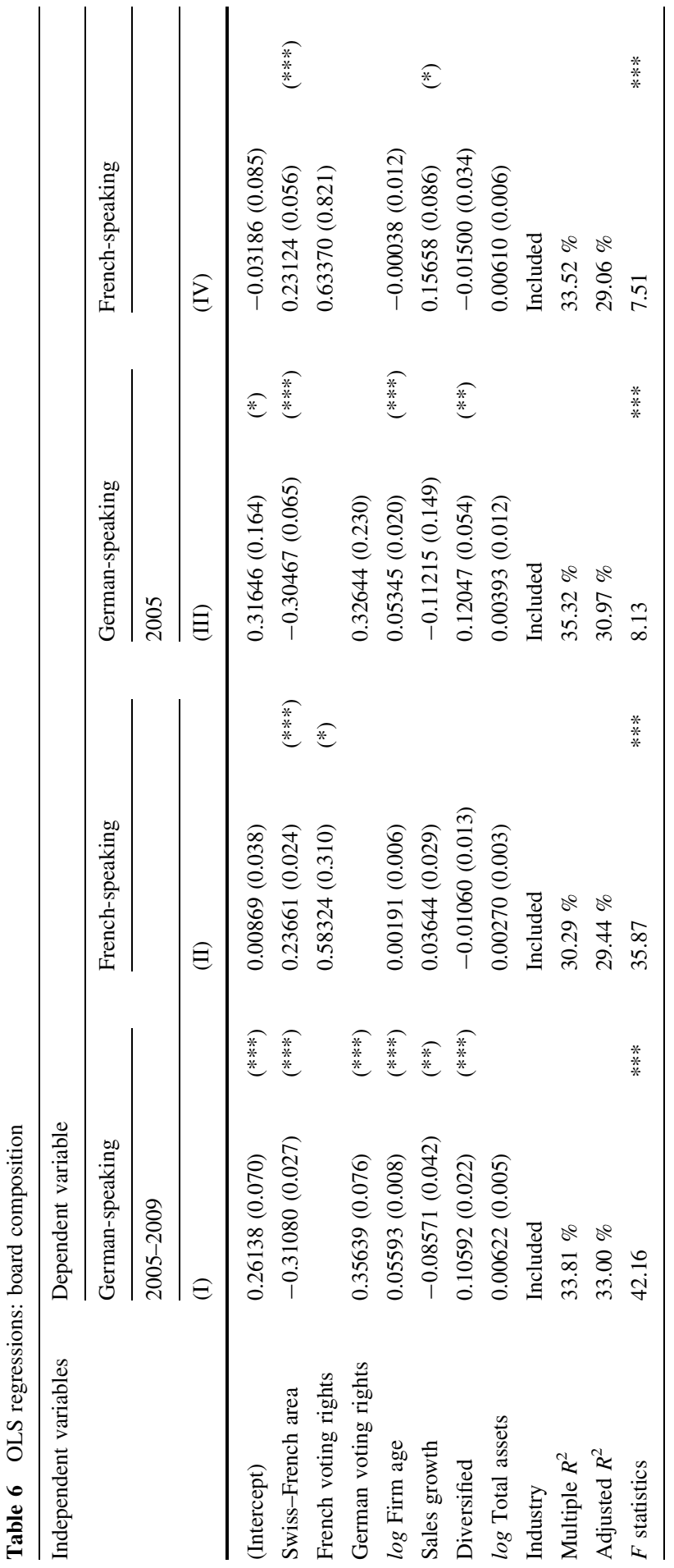




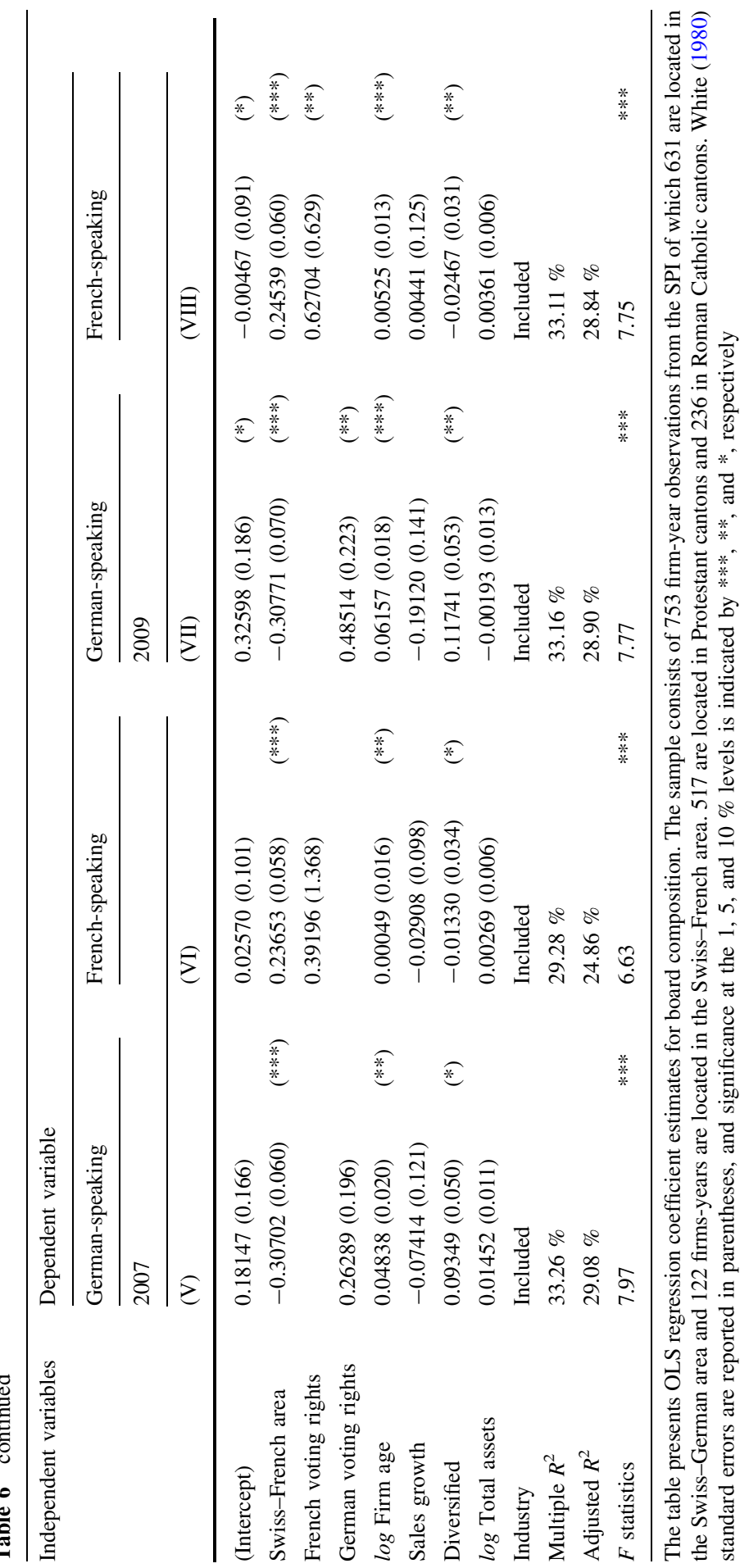




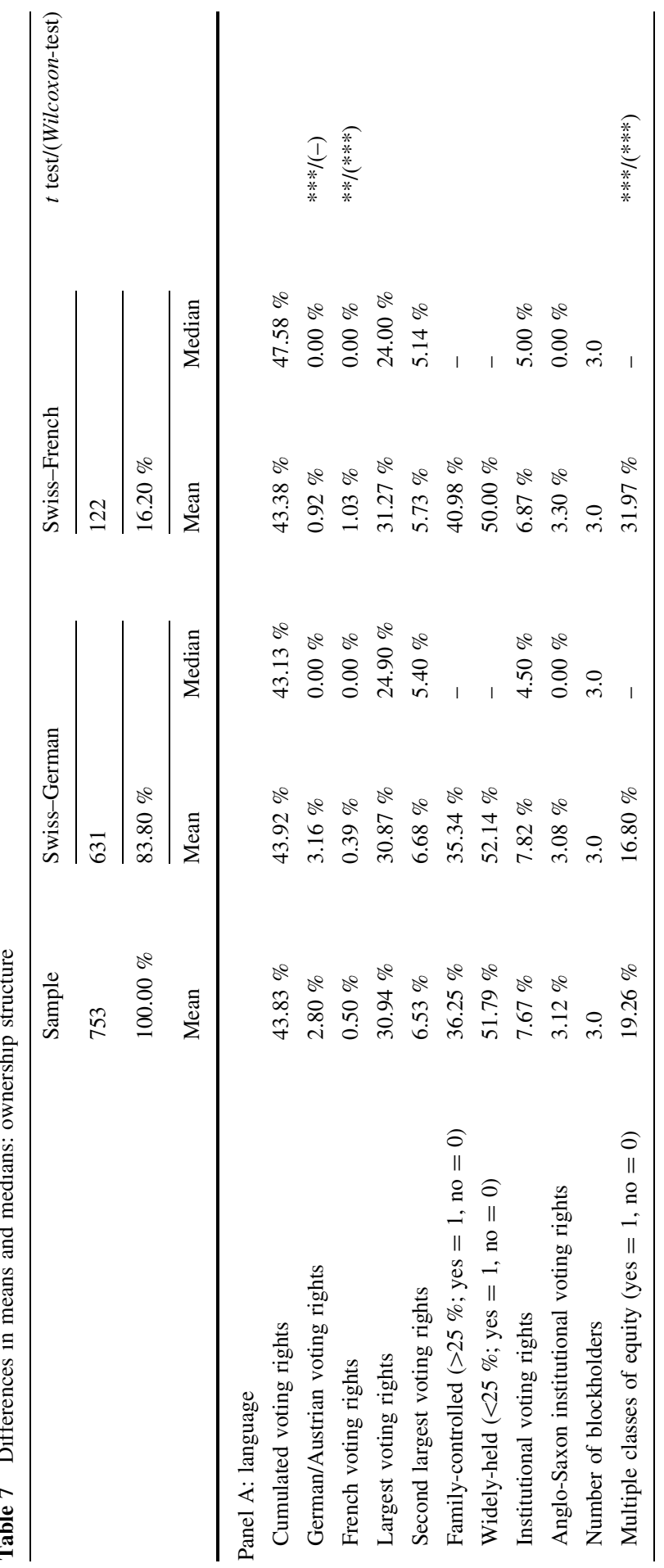




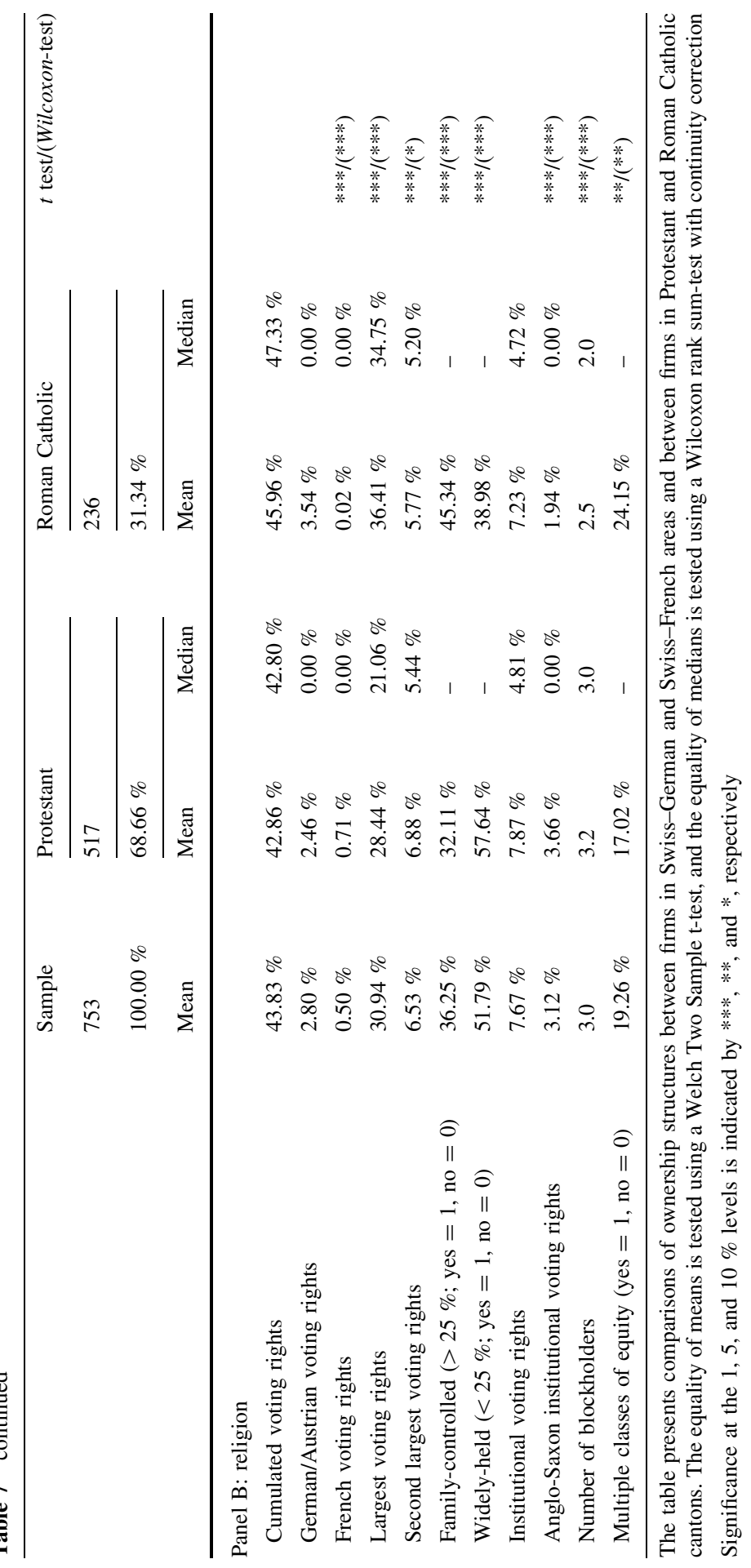




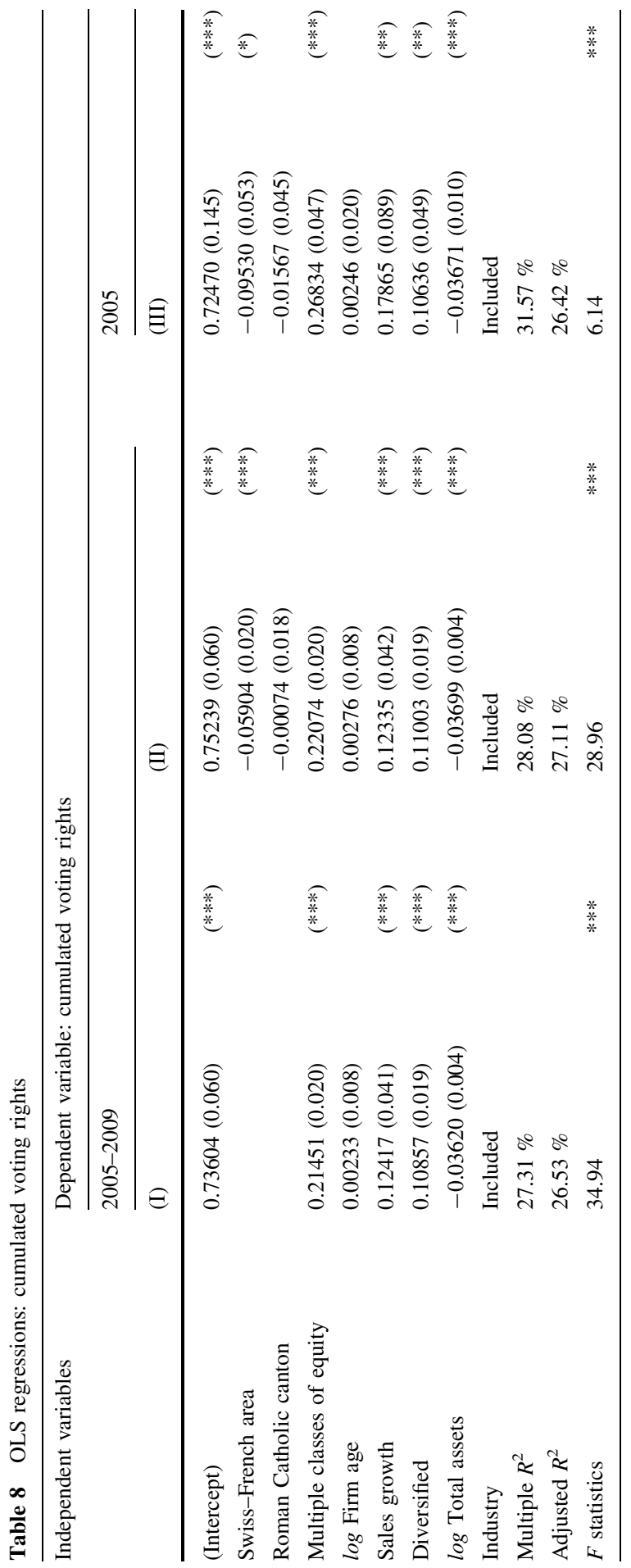

\section{글 Springer}




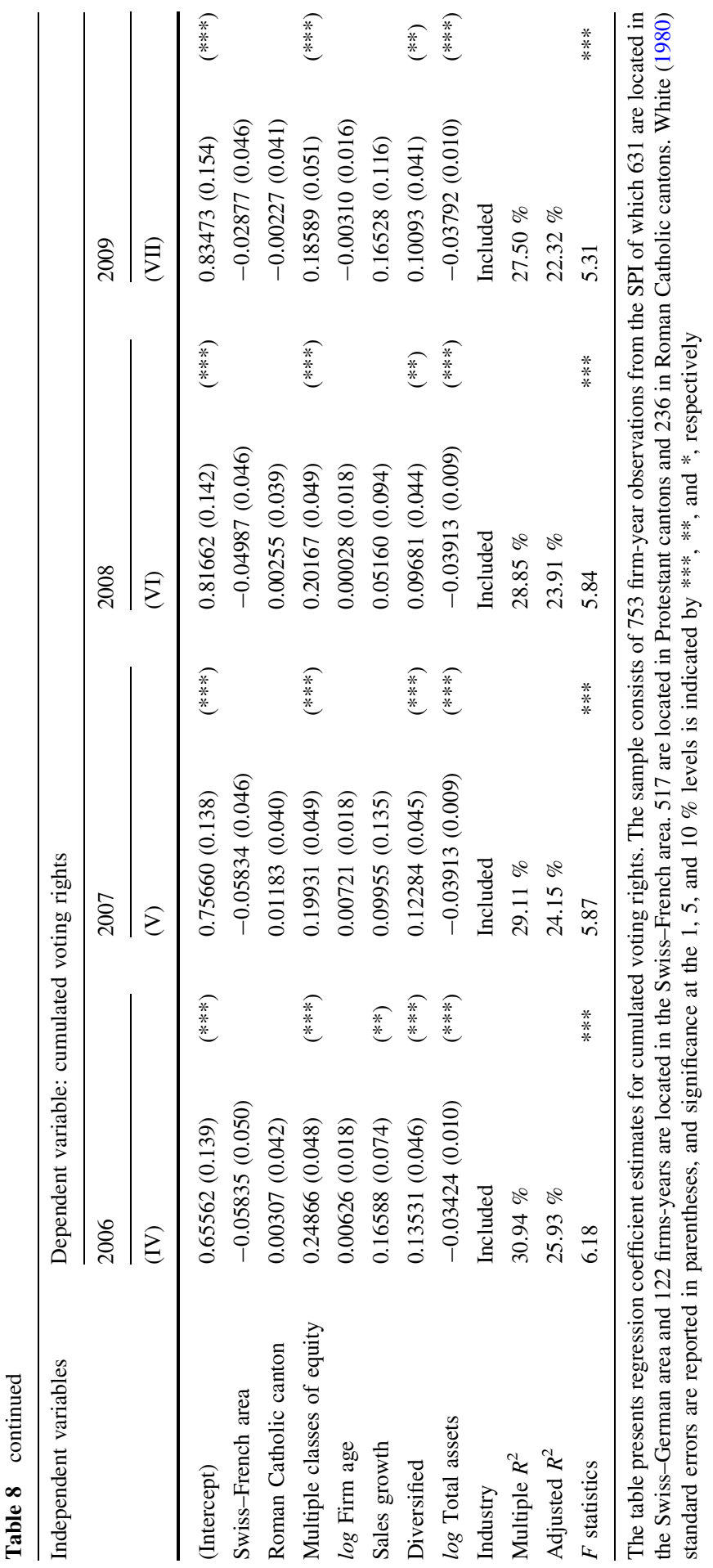




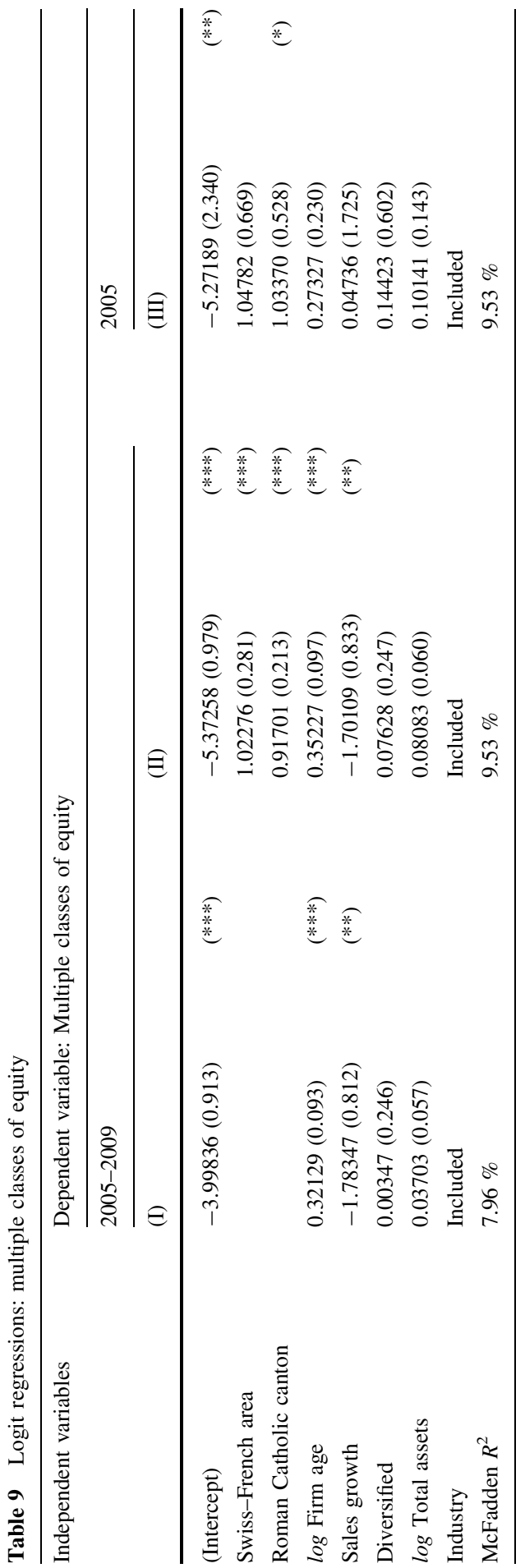

\section{글 Springer}




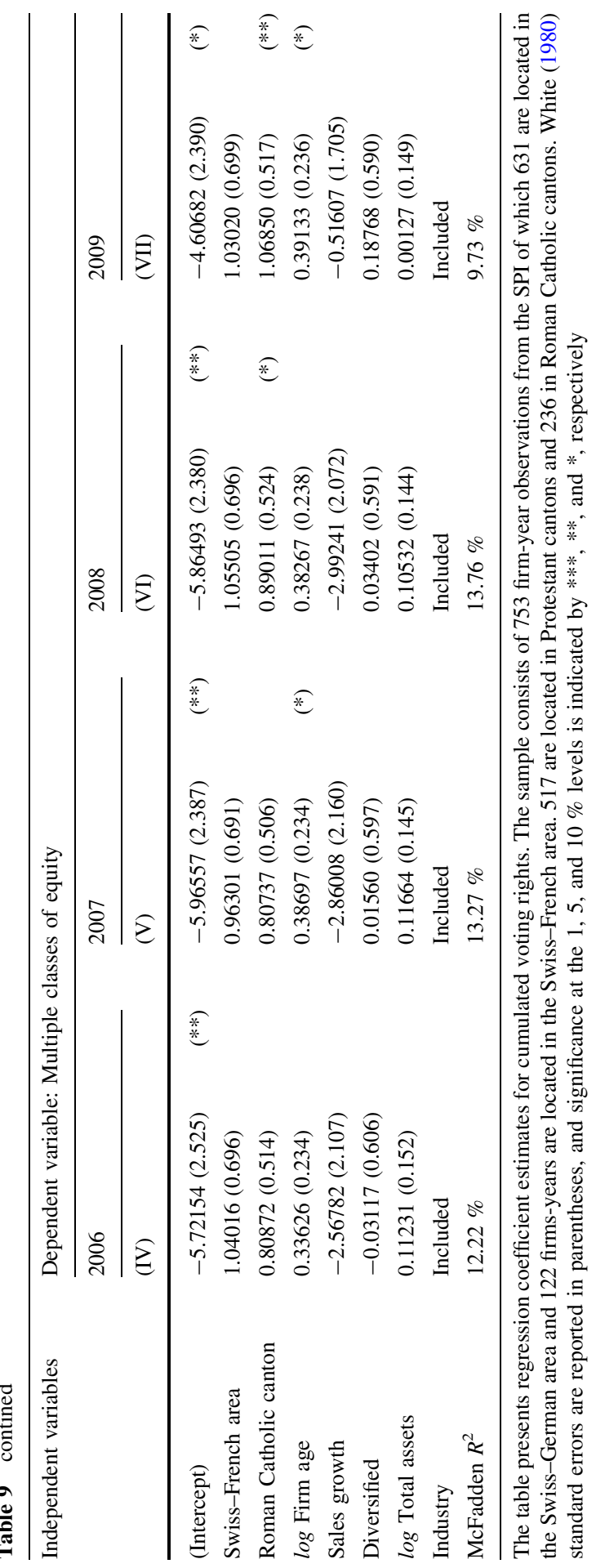




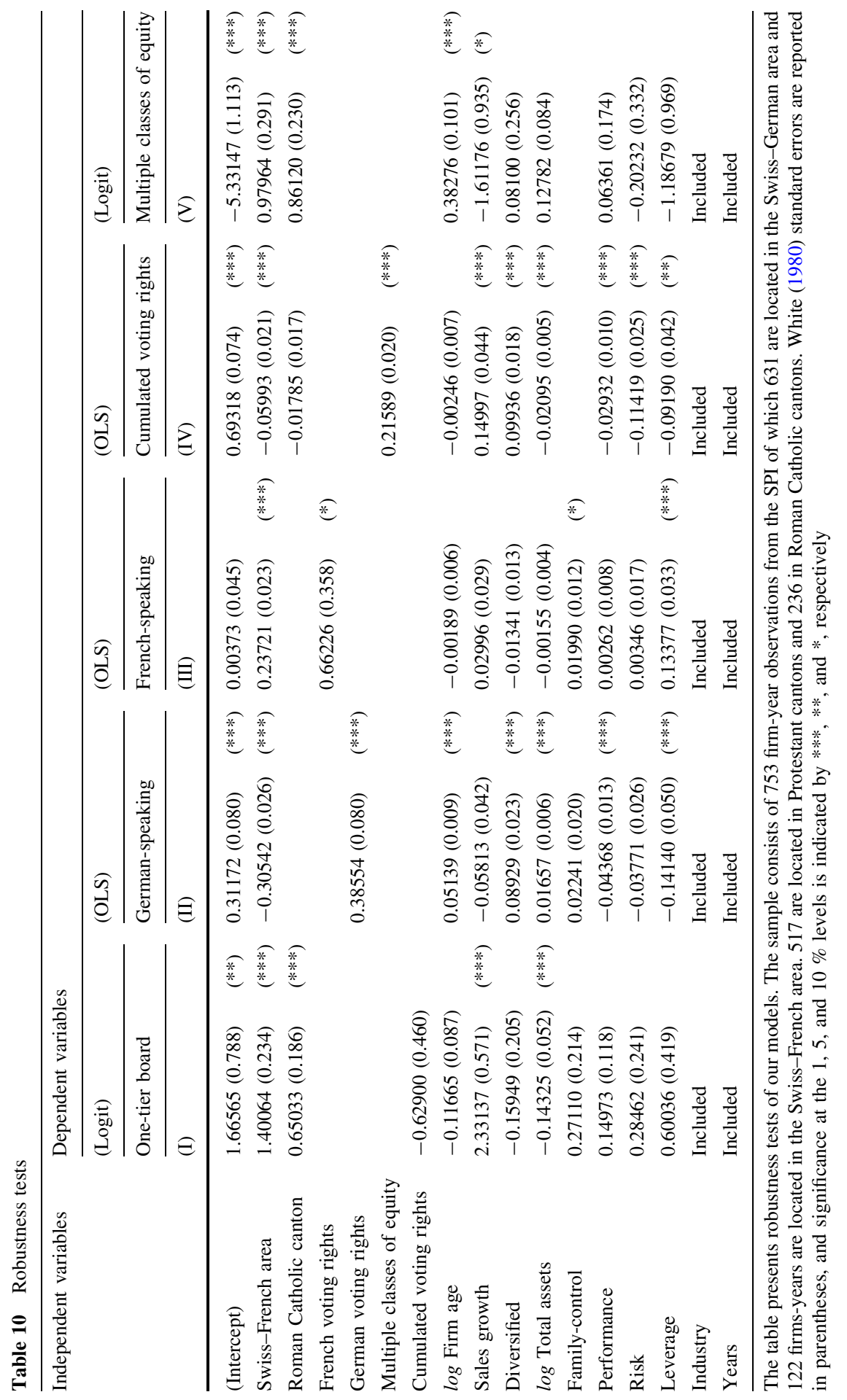


Several studies have perceived a hybridization of corporate governance systems around the world, and culture is a crucial factor in this development. However, it is essential to devise a scientific methodology that is capable of disentangling culture from the institutional environment of a country and identify causal effects. We provide empirical evidence that culture and values related to tolerance for hierarchical structures directly affect board structure. In this way, our study is important for research in the fields of international business and corporate governance. Policies that are aimed at modifying corporate governance regimes may not account for the fact that cultural values have an impact on governance practices. An optimal corporate governance regime, however, must be aligned to its respective business environment. In addition, since such culturally-determined differences are present in the corporate governance structures that exist in a small developed country like Switzerland, then the corporate governance systems of other countries in Europe and further afield economies are likely to reflect cultural characteristics, as well. It is also important to understand the persistent regional cultural differences which affect corporate governance regimes and business practices throughout the world for economic success in an increasingly globalized market. Regulators and activist shareholders should therefore be careful when proposing corporate governance reforms that follow an Anglo-American logic. Corporate governance reforms must take into account cultural differences when modifications are aimed at implementing an effective corporate governance mechanism.

However, the study has some limitations. First of all, the advantage of investigating only one country because of its unique institutional setting is also a disadvantage, because the effects of language and religion on culture may be particular to Switzerland. In the same context, the sample size is relatively small, investigating only about 150 firms each year. Some other considerations are necessary. In contrast to culture, herd behavior and network effects may be an explanation for why firms in some regions adhere to specific corporate governance practices (see e.g., Kahan and Klausner 1996). It is conceivable that Swiss-French and Swiss-German firms simply copy the corporate governance practices of their direct neighbors and adhere to their business practices owing to proximity. Switzerland's case is particular. The study on Canada shows that law is more important than culture in explaining ownership structure. Nevertheless, intra-national differences in power distance exist in Italy for instance (see Putnam 1993), and similar comparisons could be conducted in other environments. Furthermore, our analysis is restricted to listed firms that comply with national and international corporate governance standards. In particular, large multinational corporations are subject to pressure from institutional investors and the media to comply with best practices. We do not know whether cultural differences are more distinctive in non-listed firms. However, we suggest that corporate governance reformers should consider the implications of interfering with cultural customs. 
Acknowledgments I thank Thomas Clarke, Tom Kirchmaier, the three anonymous referees, and the participants at the XIII April International Academic Conference on Economic and Social Development (2012) in Moscow for their very helpful comments and discussions. I thank Hermione Miller-Moser for her editorial assistance. I acknowledge the research grant by the Föderverein WWZ (B-119). This paper is based on Chapter 4 of my PhD thesis: "Corporate Governance in Switzerland", University of Basel, 2011. Part of this paper has been written while I was a visiting scholar at the University of Technology, Sydney and I thank the University of Manchester for providing me with access to BoardEx during my research stay at the Manchester Business School.

\section{Appendix}

Table 11 Hofstede's cultural dimensions

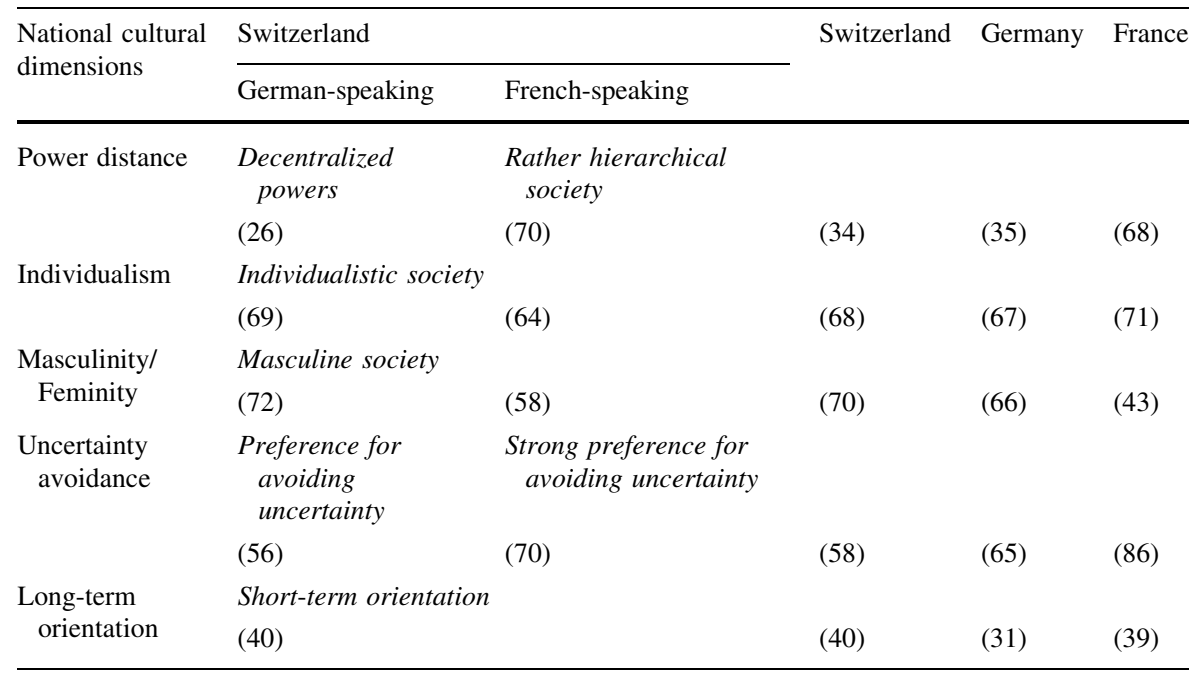

Source: Hofstede (2013)

Table 12 Population in Switzerland (2010)

\begin{tabular}{|c|c|c|}
\hline \multicolumn{3}{|c|}{ Permanent resident population of Switzerland ${ }^{\mathrm{a}}$} \\
\hline Total & $7,793,991$ & $100.00 \%$ \\
\hline Swiss & $6,103,857$ & $78.31 \%$ \\
\hline German & 263,271 & $3.38 \%$ \\
\hline French & 95,643 & $1.23 \%$ \\
\hline \multicolumn{3}{|c|}{ Permanent resident population of canton Basel-City ${ }^{a}$} \\
\hline Total & 183,118 & $100.00 \%$ \\
\hline Swiss & 124,865 & $68.19 \%$ \\
\hline German & 13,897 & $7.59 \%$ \\
\hline French & 1,365 & $0.75 \%$ \\
\hline
\end{tabular}


Table 12 continued

\begin{tabular}{|c|c|c|}
\hline \multicolumn{3}{|c|}{ Permanent resident population of canton Zurich $^{\mathrm{a}}$} \\
\hline Total & $1,364,091$ & $100.00 \%$ \\
\hline Swiss & $1,042,311$ & $76.41 \%$ \\
\hline German & 76,302 & $5.59 \%$ \\
\hline French & 5,607 & $0.41 \%$ \\
\hline \multicolumn{3}{|c|}{ Permanent resident population of canton Geneva ${ }^{a}$} \\
\hline Total & 432,720 & $100.00 \%$ \\
\hline Swiss & 278,724 & $64.41 \%$ \\
\hline German & 5,086 & $1.18 \%$ \\
\hline French & 24,589 & $5.68 \%$ \\
\hline
\end{tabular}

\footnotetext{
${ }^{a}$ Swiss, resident foreign nationals (B permit), settled foreign nationals (C permit), residence permit with gainful employment (Ci permit). Source: Swiss Federal Department of Statistics
}

\section{References}

Aggarwal, R., \& Goodell, J. W. (2010). Financial markets versus institutions in European countries: influence of culture and other national characteristics. International Business Review, 19(5), 502-520.

Aguilera, R. V., \& Jackson, G. (2003). The cross-national diversity of corporate governance: dimensions and determinants. Academy of Management Review, 28(3), 447-465.

Aguilera, R. V., \& Jackson, G. (2010). Comparative and international corporate governance. Academy of Management Annals, 4(1), 485-556.

Armour, J., Deakin, S., Sarkar, P., Siems, M., \& Singh, A. (2009). Shareholder protection and stock market development: an empirical test of the legal origins hypothesis. Journal of Empirical Legal Studies, 6(2), 343-380.

Arrunada, B. (2010). Protestants and Catholics: similar work ethic, different social ethic. Economic Journal, 120(547), 890-918.

Barro, R. J., \& McCleary, R. M. (2003). Religion and economic growth across countries. American Sociological Review, 68(5), 760-781.

Bebchuk, L. A., \& Roe, M. J. (1999). A theory of path dependence in corporate ownership and governance. Stanford Law Review, 52(1), 127-170.

Beck, T., Demirgüç-Kunt, A., \& Levine, R. (2003). Law, endowments, and finance. Journal of Financial Economics, 70(2), 137-181.

Beck, T., \& Webb, I. (2003). Economic, demographic, and institutional determinants of life insurance consumption across countries. World Bank Economic Review, 17(1), 51-88.

Becker, B., Cronqvist, H., \& Fahlenbrach, R. (2008). Estimating the effects of large shareholders using a geographic instrument. Working Paper, Swedish House of Finance, Stockholm.

Becker, S. O., \& Woessmann, L. (2009). Was Weber wrong? a human capital theory of Protestant economic history. Quarterly Journal of Economics, 124(2), 531-596.

Black, B. S., \& Khanna, V. S. (2007). Can corporate governance reforms increase firm market values? Event study evidence from India. Journal of Empirical Legal Studies, 4(4), 749-796.

Boone, A. L., Field, L. C., Karpoff, J. M., \& Raheja, C. G. (2007). The determinants of corporate board size and composition: an empirical analysis. Journal of Financial Economics, 85(1), 66-101.

Booth, J. R., Cornett, M. M., \& Tehranian, H. (2002). Boards of directors, ownership, and regulation. Journal of Banking \& Finance, 26(10), 1973-1996.

Boubraki, N., Bozec, Y., Laurin, C., \& Rousseau, S. (2011). Incorporation law, ownership structure, and firm value: evidence from Canada. Journal of Empirical Legal Studies, 8(2), 358-383.

Bozec, Y., Rousseau, S., \& Laurin, C. (2008). Law of incorporation and firm ownership structure: the law and finance theory revisited. International Review of Law and Economics, 28(2), 140-149. 
Brügger, B., Lalive, R., \& Zweimüller, J. (2009). Does culture affect unemployment? evidence from the Röstigraben. CESifo Working Paper Series No. 2714, Munich.

Buck, T., \& Shahrim, A. (2005). The translation of corporate governance changes across national cultures: the case of Germany. Journal of International Business Studies, 36(1), 42-61.

Chakrabarti, R., Gupta-Mukherjee, S., \& Jayaraman, N. (2008). Mars-Venus marriages: culture and cross-border M\&A. Journal of International Business Studies, 40(2), 216-236.

Chui, A. C. W., Lloyd, A. E., \& Kwok, C. C. Y. (2002). The determination of capital structure: is national culture a missing piece to the puzzle? Journal of International Business Studies, 33(1), 99-127.

Clarke, T., \& dela Rama, M. J. (2006). The governance of globalization. In T. Clarke \& M. J. dela Rama (Eds.), Corporate governance and globalization. London: Sage Publications.

Coffee, J. C. (2001). The rise of dispersed ownership: the roles of law and the state in the separation of ownership and control. Yale Law Journal, 111(1), 1-82.

Coles, J. L., Daniel, N. D., \& Naveen, L. (2008). Boards: does one size fit all? Journal of Financial Economics, 87(2), 329-356.

Daines, R. (2001). Does Delaware law improve firm value? Journal of Financial Economics, 62(3), 525-558.

Daniel, S. J., Cieslewicz, J. K., \& Pourjalali, H. (2012). The impact of national economic culture and country-level institutional environment on corporate governance practices. Management International Review, 52(3), 365-394.

Demb, A., \& Neubauer, F. (1992). The corporate board: confronting the paradoxes. Long Range Planning, 25(3), 9-20.

Denis, D. K., \& McConnell, J. J. (2003). International corporate governance. Journal of Financial and Quantitative Analysis, 38(1), 1-36.

Djankov, S., Glaeser, E., La Porta, R., Lopez-de-Silanes, F., \& Shleifer, A. (2003). The new comparative economics. Journal of Comparative Economics, 31(4), 595-619.

Doidge, C., Karolyi, G. A., \& Stulz, R. M. (2007). Why do countries matter so much for corporate governance? Journal of Financial Economics, 86(1), 1-39.

Dorn, D., Fischer, J. A. V., Kirchgässner, G., \& Sousa-Poza, A. (2008). Direct democracy and life satisfaction revisited: new evidence for Switzerland. Journal of Happiness Studies, 9(2), 227-255.

Douma, S. (1997). The two-tier system of corporate governance. Long Range Planning, 30(4), 612-614.

Dyck, A., \& Zingales, L. (2004). Private benefits of control: an international comparison. Journal of Finance, 59(2), 537-600.

Faccio, M., \& Lang, L. H. P. (2002). The ultimate ownership of Western European corporations. Journal of Financial Economics, 65(3), 365-395.

Fahlenbrach, R., Low, A., \& Stulz, R. M. (2010). Why do firms appoint CEOs as outside directors? Journal of Financial Economics, 97(1), 12-32.

Franke, R. H., Hofstede, G., \& Bond, M. H. (1991). Cultural roots of economic performance: a research note. Strategic Management Journal, 12(S1), 165-173.

Gillan, S. L., \& Starks, L. T. (2007). The evolution of shareholder activism in the United States. Journal of Applied Corporate Finance, 19(1), 55-73.

Glaeser, L., \& Glendon, S. (1998). Incentives, predestination and free will. Economic Inquiry, 36(3), 429-443.

Glahe, F., \& Vohries, F. (1989). Religion, liberty and economic development: an empirical investigation. Public Choice, 62(3), 201-215.

Goyer, M. (2006). Varieties of institutional investors and national models of capitalism: the transformation of corporate governance in France and Germany. Politics and Society, 34(3), 399-430.

Grinblatt, M., \& Keloharju, M. (2001). How distance, language and culture influence stockholdings and trades. Journal of Finance, 56(3), 1053-1073.

Guiso, L., Sapienza, P., \& Zingales, L. (2003). People's opium? religion and economic attitudes. Journal of Monetary Economics, 50(1), 225-282.

Guiso, L., Sapienza, P., \& Zingales, L. (2006). Does culture affect economic outcomes? Journal of Economic Perspectives, 20(2), 23-48.

Guiso, L., Sapienza, P., \& Zingales, L. (2009). Cultural biases in economic exchange? Quarterly Journal of Economics, 124(3), 1095-1131.

Hansmann, H., \& Kraakman, R. (2000). The end of history for corporate law. Harvard Law School John M. Olin Center for Law, Economics and Business Discussion Paper Series. Paper 280, Cambridge. 
Hayward, R. D., \& Kemmelmeier, M. (2011). Weber revisited: a cross-national analysis of religiosity, religious culture, and economic attitudes. Journal of Cross-Cultural Psychology, 42(8), 1406-1420.

Heidrick, \& Struggles (2011). Challenging board performance: European corporate governance report 2011, Chicago. available at http://www.heidrick.com.

Hilary, G., \& Hui, K. W. (2009). Does religion matter in corporate decision making in America? Journal of Financial Economics, 93(3), 455-473.

Hofstede, G. (1980). Culture's consequences: international differences in work-related values. Beverly Hills: Sage Publications.

Hofstede, G. (2013). National cultural dimensions. http://www.geert-hofstede.com. Accessed 18 May 2013.

Hopt, K. J., \& Leyens, P. C. (2004). Board models in Europe-recent developments of internal corporate governance structures in Germany, the United Kingdom, France, and Italy. European Company and Financial Law Review, 1(2), 135-168.

Jungmann, C. (2006). The effectiveness of corporate governance in one-tier and two-tier board systems: evidence from the UK and Germany. European Company and Financial Law Review, 3(4), 426-474.

Kahan, M., \& Klausner, M. (1996). Path dependence in corporate contracting: increasing returns, herd behavior and cognitive biases. Washington University Law Quarterly, 74(2), 347-366.

Kang, J. K., \& Kim, J. M. (2008). The geography of block acquisitions. Journal of Finance, 63(6), 2817-2858.

Khanna, T., Kogan, J., \& Palepu, K. (2006). Globalization and similarities in corporate governance: a cross-country analysis. Review of Economics and Statistics, 88(1), 69-90.

Kogut, B., \& Singh, H. (1988). The effect of national culture on the choice of entry mode. Journal of International Business Studies, 19(3), 411-432.

La Porta, R., Lopez-de-Silanes, F., \& Shleifer, A. (1999a). Corporate ownership around the world. Journal of Finance, 54(2), 471-517.

La Porta, R., Lopez-de-Silanes, F., \& Shleifer, A. (2008). The economic consequences of legal origins. Journal of Economic Literature, 46(2), 285-332.

La Porta, R., Lopez-de-Silanes, F., Shleifer, A., \& Vishny, R. (1997). Trust in large organizations. American Economic Review, 87(2), 333-338.

La Porta, R., Lopez-de-Silanes, F., Shleifer, A., \& Vishny, R. (1998). Law and finance. Journal of Political Economy, 106(6), 1113-1155.

La Porta, R., Lopez-de-Silanes, F., Shleifer, A., \& Vishny, R. (1999b). The quality of government. Journal of Law Economics and Organization, 15(1), 222-279.

La Porta, R., Lopez-de-Silanes, F., Shleifer, A., \& Vishny, R. (2000). Investor protection and corporate governance. Journal of Financial Economics, 58(1-2), 3-27.

Lehn, K. M., Patro, S., \& Zhao, M. (2009). Determinants of the size and composition of US corporate boards: 1935-2000. Financial Management, 38(4), 747-780.

Levine, D. H. (1979). Religion and politics, politics and religion: an introduction. Journal of InterAmerican Studies and World Affairs, 21(1), 5-29.

Li, J., \& Harrison, J. R. (2008). National culture and the composition and leadership structure of boards of directors. Corporate Governance, 16(5), 375-385.

Licht, A. N. (2001). The mother of all path dependencies: towards a cross-cultural theory of corporate governance systems. Delaware Journal of Corporate Law, 26(1), 147-205.

Licht, A. N., Goldschmidt, C., \& Schwartz, S. H. (2005). Culture, law, and corporate governance. International Review of Law and Economics, 25(2), 229-255.

Licht, A. N., Goldschmidt, C., \& Schwartz, S. H. (2007). Culture rules: the foundations of the rule of law and other norms of governance. Journal of Comparative Economics, 35(4), 659-688.

Linck, J. S., Netter, J. M., \& Yang, T. (2008). The determinants of board structure. Journal of Financial Economics, 87(2), 308-328.

Lowe, S. (1998). Culture and network institutions in Hong Kong: a hierarchy of perspectives. a response to Wilkinson: 'Culture, institutions and business in East Asia'. Organization Studies, 19(2), 321-344.

Lüpold, M., \& Schnyder, G. (2009). Horse, cow, sheep, or 'thing-in-itself'? the cognitive origins of corporate governance in Switzerland, Germany, and the US, 1910s-1930s. Centre for Business Research, University of Cambridge Working Paper No. 383.

Mayer, K. (1951). Cultural pluralism and linguistic equilibrium in Switzerland. American Sociological Review, 16, 157-163. 
Millet-Reyes, B., \& Zhao, R. (2010). A comparison between one-tier and two-tier board structures in France. Journal of International Financial Management and Accounting, 21(3), 279-310.

Nickell, S. (1997). Unemployment and labor market rigidities: Europe versus North America. Journal of Economic Perspectives, 11(3), 55-74.

Noland, M. (2005). Religion and economic performance. World Development, 33(8), 1215-1232.

North, D. (1990). Institutions, institutional change, and economic performance. Cambridge: Harvard University Press.

Putnam, R. (1993). Making democracy work: civic traditions in modern Italy. Princeton: Princeton University Press.

Rajan, R. G., \& Zingales, L. (2003). The great reversals: the politics of financial development in the twentieth century. Journal of Financial Economics, 69(1), 5-50.

Roe, M. J. (1991). A political theory of American corporate finance. Columbia Law Review, 91(1), 10-67.

Roe, M. J. (1999). German codetermination and German securities markets. Columbia Journal of European Law, 5(2), 199-212.

Ronen, S., \& Shenkar, O. (1985). Clustering countries on attitudinal dimensions: a review and synthesis. Academy of Management Review, 10(3), 435-454.

Schwartz, S. H. (1999). A theory of cultural values and some implications for work. Applied Psychology, $48(1), 23-47$.

Shenkar, O. (2001). Cultural distance revisited: towards a more rigorous conceptualization and measurement of cultural differences. Journal of International Business Studies, 32(3), 519-535.

Shleifer, A., \& Vishny, R. (1997). A survey of corporate governance. Journal of Finance, 52(2), 737-783.

Siegel, J. I., Licht, A. N., \& Schwartz, S. H. (2011). Egalitarianism and international investment. Journal of Financial Economics, 102(3), 621-642.

Slangen, A. H. L., \& van Tulder, R. J. M. (2009). Cultural distance, political risk, or governance quality? towards a more accurate conceptualization and measurement of external uncertainty in foreign entry mode research. International Business Review, 18(3), 276-291.

Stahl, G. K., \& Voigt, A. (2008). Do cultural differences matter in mergers and acquisitions? a tentative model and examination. Organization Science, 19(1), 160-176.

Storck, M. (2004). Corporate governance à la Française-current trends. European Company and Financial Law Review, 1(1), 36-59.

Stulz, R. M., \& Williamson, R. (2003). Culture, openness, and finance. Journal of Financial Economics, 70(3), 313-349.

Tang, L., \& Koveos, P. E. (2008). A framework to update Hofstede's cultural value indices: economic dynamics and institutional stability. Journal of International Business Studies, 39(6), 1045-1063.

Tihanyi, L., Griffith, D. A., \& Russell, C. J. (2005). The effect of cultural distance on entry mode choice, international diversification, and MNE performance: a meta-analysis. Journal of International Business Studies, 36(3), 270-283.

Weber, M. (1930). The protestant ethic and the spirit of capitalism. New York: Harper Collins.

White, H. (1980). A heteroskedasticity-consistent covariance matrix estimator and a direct test for heteroskedasticity. Econometrica, 48(4), 817-838.

Williamson, O. E. (2000). The new institutional economics: taking stock, looking ahead. Journal of Economic Literature, 38(3), 595-613.

Wymeersch, E. (1998). A status report on corporate governance rules and practices in some Continental European states. In K. J. Hopt, H. Kanda, M. J. Roe, E. Wymeersch, \& S. Prigge (Eds.), Comparative corporate governance: the state of the art and emerging research. Oxford: Clarendon Press.

Yoshikawa, T., Tsui-Auch, L. S., \& McGuire, J. (2007). Corporate governance reform as institutional innovation: the case of Japan. Organization Science, 18(6), 973-988. 